Article

\title{
Optimization of RC Structures in Terms of Cost and Environmental Impact-Case Study
}

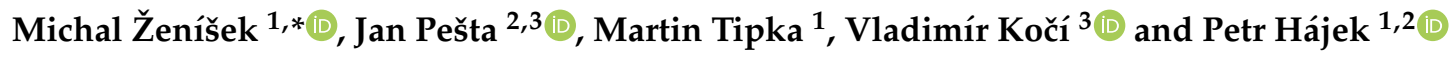 \\ 1 Faculty of Civil Engineering, Czech Technical University in Prague, 16629 Prague 6, Czech Republic; \\ martin.tipka@fsv.cvut.cz (M.T.); petr.hajek@fsv.cvut.cz (P.H.) \\ 2 Department Architecture and the Environment, University Centre for Energy Efficient Buildings, \\ Czech Technical University in Prague, 16000 Prague 6, Czech Republic; pestaj@vscht.cz \\ 3 Faculty of Environmental Technology, University of Chemistry and Technology, 16628 Prague 6, \\ Czech Republic; kociv@vscht.cz \\ * Correspondence: michal.zenisek@fsv.cvut.cz
}

Received: 12 September 2020; Accepted: 13 October 2020; Published: 15 October 2020

\begin{abstract}
Reinforced concrete (RC) structures represent one of the most widespread building systems around the world. This paper deals with the optimization of load-bearing RC structures in terms of cost and environmental impact. The results of the optimization are the dimensions and reinforcement of structural elements for which the total construction costs and environmental impacts are the lowest. Six variants of RC building structures were designed and analyzed in a case study. The construction cost was evaluated on the basis of the national pricing system. The life cycle assessment (LCA) characterization model according to the ReCiPe methodology version 1.08 was used to assess environmental impacts. The main motivation of this article was to show the possibilities of the multi-criteria optimization of a load-bearing structure, not only from a structural point of view but also from economic and environmental points of view. The presented conclusions correspond to this specific construction of the RC structure used in the case study and may not be generalized. Nevertheless, they point to certain trends and patterns that can also be used in the design of other reinforced concrete structures. The method used in this case study could be applied to the analysis of other structures using specific datasets for cost and environmental impact evaluation.
\end{abstract}

Keywords: LCA; reinforced concrete; columns; floor slabs; multi-criteria optimization; exhaustive search

\section{Introduction}

Nowadays, great emphasis is placed on sustainable development and particularly on environmental protection [1]. In the construction industry, the basic principles of sustainable construction mainly include the efficient use of raw materials (the reduction of consumption of primary raw materials and the use of renewable and recyclable raw materials), the reduction of energy and water consumption, efficient waste management, effective land use, economic efficiency, and creating a healthy indoor environment [2]. Sustainable construction is therefore a feasible compromise among environmental, economic, and social requirements. This differs from the traditional approach that primarily pursues economic interests of construction.

Reinforced concrete (RC) structures occupy a dominant position in construction in developed and in developing countries. The consumption of cement, a key raw material for concrete production, is rising every year [3], and this trend will continue [4]. The high consumption of cement is associated with a large amount of $\mathrm{CO}_{2}$ emissions released into the air. Many researchers have therefore been focused on this key issue of trying to reduce $\mathrm{CO}_{2}$ consumption in the production of concrete [5-9]. 
The most common approaches are the use of alternative fuels in cement production, the replacement of Portland clinker with other low-carbon supplementary cementitious materials, and the development of alternative low-carbon binders [10-12]. Another approach is the optimization of the load-bearing structure, which can reduce the total amount of concrete during construction, as well as the production of construction waste at the end of the life of the structure [13].

Optimization can be based on different goals and solution strategies [14-16]. In the last 20 years, the literature has addressed the following high priority topics in the optimization of buildings:

1. Optimization of environmental impacts-energy consumption, greenhouse gas emissions, life cycle assessment (LCA), waste production, etc.

2. Optimization of construction costs-production costs, operating costs, life cycle cost, etc.

However, other cases of optimization are also known such as user comfort, construction reliability, and daylighting performance. Very often, the problem is solved using a multi-criteria approach when it is necessary to find the optimal solution for multiple purpose functions (often contradictory) in the form of a Pareto optimum. Such a complex problem could be solved by converting from multi-criteria to mono-criteria (e.g., using weight constants). There are several numerical methods that can be used to find the global minimum (or maximum) $[14,17,18]$. These methods could provide satisfactory results in classical cases. In cases where the task has more optimization variables (typically more than 30), finding a suitable solution using these methods is time-consuming. Therefore, it is appropriate to reduce the number of optimization variables or to narrow the constraints.

If the optimization variables are discrete, the number of feasible solutions is finite. In such a case, it is possible to avoid the use of numerical optimization methods and to find the optimal solution by searching the whole feasible set (exhaustive search) $[19,20]$. This set must not be too large, and the time required to calculate one solution must be reasonably short. However, the search for the optimal solution could be interrupted at any time and resumed from the same place where the calculation was interrupted. Using this approach, it is possible to find a real global minimum in feasible time. This approach was used in presented study.

The purpose of this study is to answer the question: What type of concrete (low, medium, or high strength) is economically and environmentally favorable for the construction of load-bearing RC structures? It is quite clear that a load-bearing structure made of high strength concrete will be subtler than a load-bearing structure made of ordinary low strength concrete. Likewise, the cost of transportation, formwork, and transfer of material at the construction site will be smaller. On the other hand, the construction costs and environmental impacts associated with the use of a higher class of concrete are significantly higher than those of ordinary concrete. At the same time, the percentage of reinforcement is higher for subtle elements, i.e., steel consumption will be higher for such a structure. It is obvious that it is not possible to decide in advance which type of concrete is suitable for a given structure, and the answer to the above question therefore requires a comprehensive assessment. This study considered the amount of consumed concrete and reinforcement, transportation costs, formwork, and transfer of materials at the construction site.

The main objective of this study was the optimization of a load-bearing RC structure in the design phase. To ensure the sufficient credibility of the results, a total of six variants of load-bearing structures were created, and these were compared with each other. The objective of the optimization (for all variants) was to minimize the construction costs and environmental impacts of the construction. As it turned out during calculations, both of these optimization criteria are closely related and there is a very strong positive correlation between them (more than 96\%). Thus, although it is a multi-criteria optimization, the problem can be separately solved for each objective function. In other words, the optimal solution for one criterion will be optimal for the second criterion as well. 


\section{Methodology}

\subsection{Optimized Building}

The optimization of a load-bearing structure was performed on a simple office building that was specially designed for the purposes of this study. The design was focused primarily on the easy optimization of the building and also on the possibility of dividing the building into several variants that could be compared with each other. Compared to a real structure, this building had certain simplifications:

- Rectangular floor plan with dimensions $42 \times 26 \mathrm{~m}$.

- Regular grid of columns.

- Identical column cross-section in the whole floor (but not in the whole building).

- Identical floor slab thickness on all floors.

- Identical floor plan on all floors.

- Identical construction height $3.3 \mathrm{~m}$ for all stories.

- $\quad$ The absence of underground floors.

It is obvious from an architectural point of view that this is a very simple concept of a building that would probably not meet the expectations of an investor or the creative ideas of an architect. However, from a functional point of view, the building is fully sufficient for office purposes. Thanks to these simplifications, the mentioned concept was suitable for the implementation of a detailed optimization study, as the building could be easily divided into these variants:

- Three height variants-4, 8, and 12 stories (Figure 1)

- $\quad$ Two span variants_column spacing of 4 and $8 \mathrm{~m}$ (Figures 2 and 3)

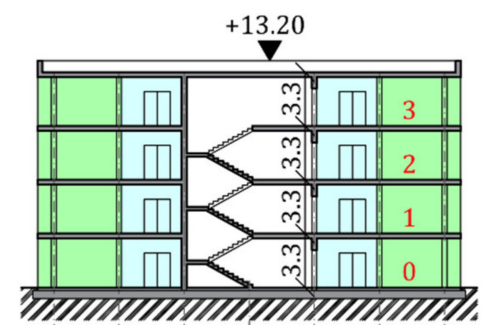

(A) (B) (C) (D) (E) F (G)

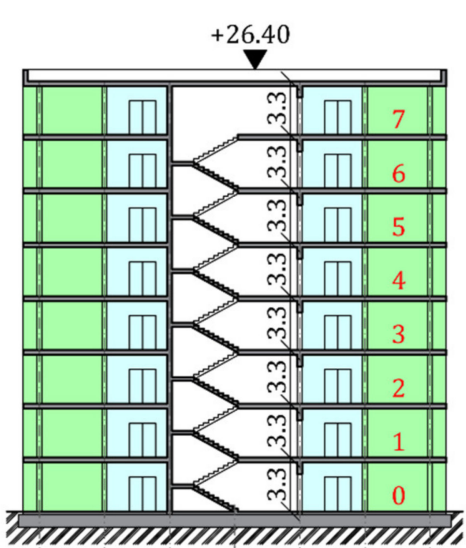

(A) (B) (C) (D) (E) F (G)

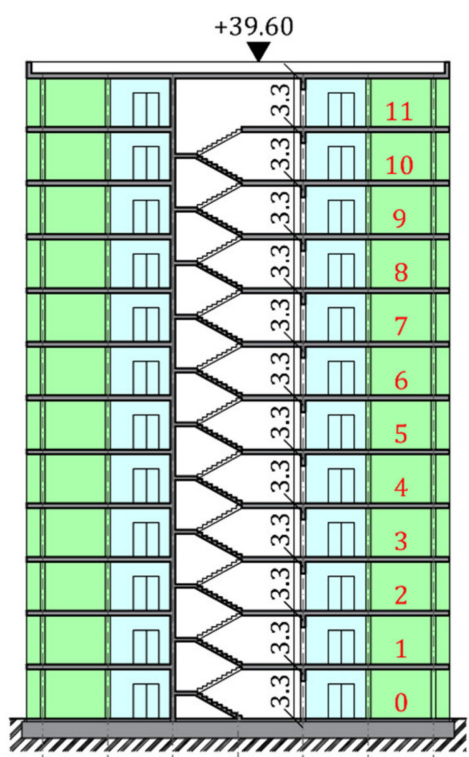

(A) (B) C (D) (E) F (G)

Figure 1. Three variants of buildings with different heights. 


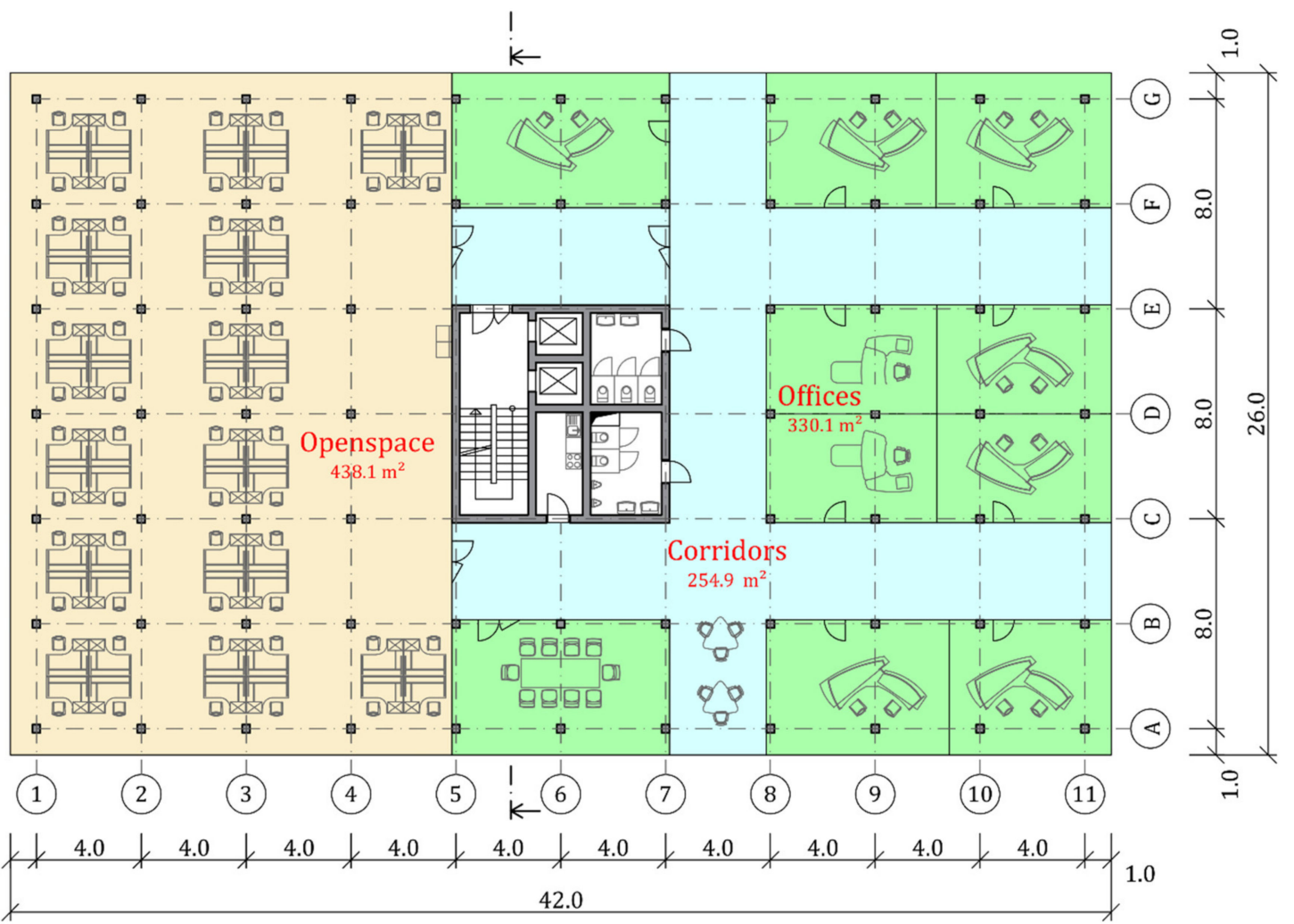

Figure 2. A variant with a column spacing of $4 \mathrm{~m}$.

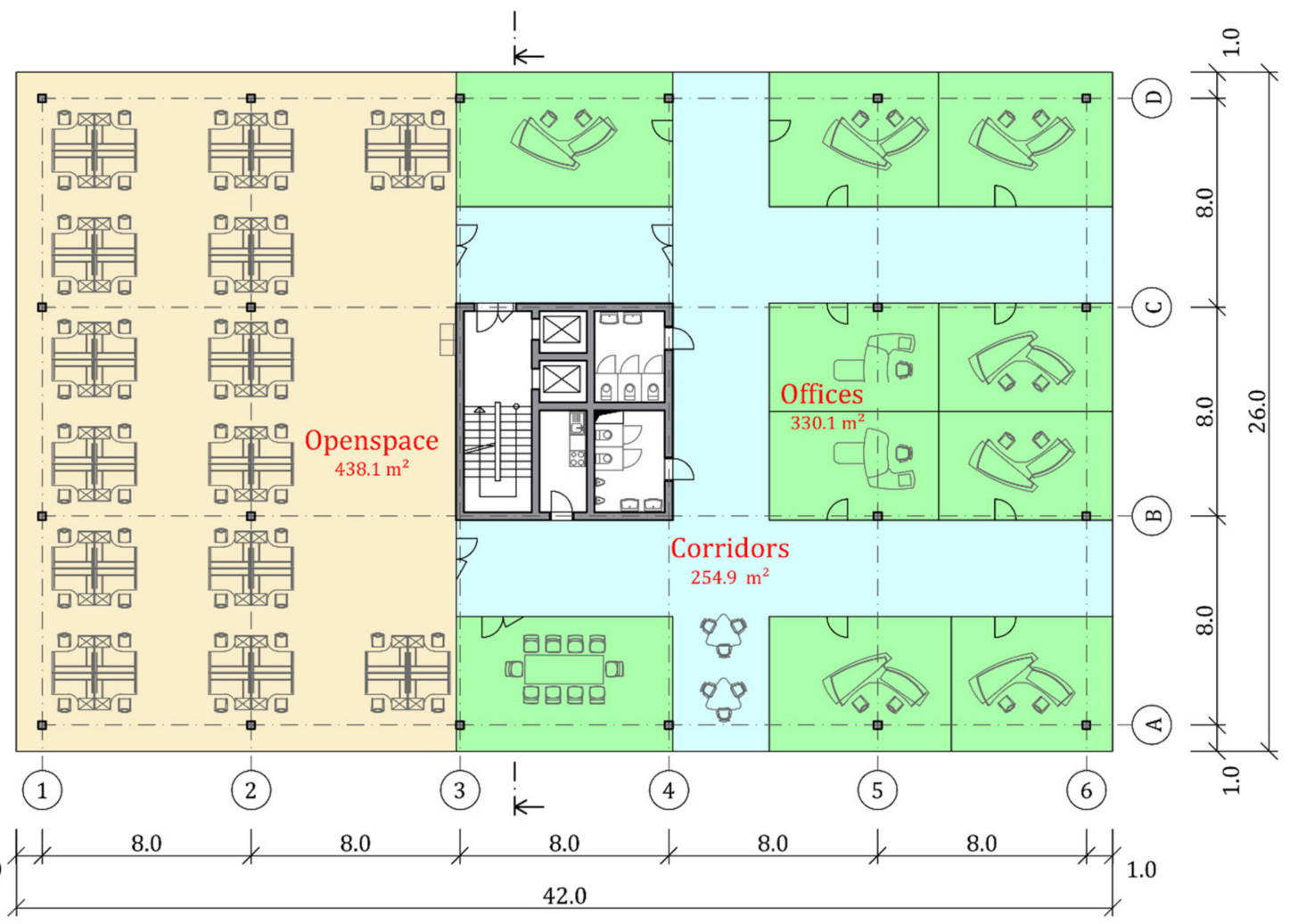

Figure 3. A variant with a column spacing of $8 \mathrm{~m}$. 
In total, six variants of the building were made, and these were independently optimized. The optimization process is strongly dependent on the type of construction. It is also possible to optimize a whole structure or only a part of it. In any case, the correct and logical design of a structure is a basic prerequisite for effective optimization; conversely, unrealistic or illogical design will not save any optimization.

Floor layouts are not important from the point of view of optimization and are only shown to illustrate a possible arrangement (the layout is the same for both span variants). The reinforcing RC core was chosen to be located in the middle of the building.

\subsection{Formulation of Optimization Problem}

The goal was to optimize dimensions the load-bearing structure so that its structural elements are used in the most efficient way. For this reason, the following parameters were chosen as optimization variables: (a) column cross-section, (b) floor slab thickness, and (c) the strength class of concrete. The column cross-section and the floor slab thickness were determined by the possibilities of the formwork, and the strength class of the concrete followed from the standard requirements. All three variables were discrete characters with a known set of values:

1. Column cross section: $200 \times 200,250 \times 250,300 \times 300,350 \times 350,400 \times 400,450 \times 450,500 \times 500$, $550 \times 550,600 \times 600,650 \times 650,700 \times 700,750 \times 750$, and $800 \times 800 \mathrm{~mm}$ (13 values).

2. Floor slab thickness: 120, 130, 140, 150, 160, 170, 180, 190, 200, 210, 220, 230, 240, 250, 260, 270, 280, $290,300,310$, and $320 \mathrm{~mm}$ (21 values).

3. Strength class of the concrete: 7 ordinary concretes-C20/25, C25/30, C30/37, C35/45, C40/50, C45/55, and C50/60 - and 3 high strength concrete-C60/70, C70/80, and C80/95 (10 values).

The first optimization variable, the column cross-section, considers a square cross-section with dimensions of $200 \times 200$ to $800 \times 800 \mathrm{~mm}$. Dimensions smaller than $200 \times 200 \mathrm{~mm}$ are not possible for technological reasons (problems with stability, reinforcement, accuracy, etc.), and dimensions larger than $800 \times 800$ are uneconomical. Between these boundaries, the column cross-section was varied with a side increment of $50 \mathrm{~mm}$, which corresponded to the possibilities of the system formwork. The column cross-section was the same for all columns within the floor but not in the whole building. Due to the fact that the load on the column decreases in height, the column cross-section was reduced by $50 \mathrm{~mm}$ every two stories.

The second optimization variable, the floor slab thickness of the floor slab, assumes a minimum value of $120 \mathrm{~mm}$. A smaller thickness is theoretically possible, but, again, we would get into technological problems with reinforcement, acoustic requirements, deflection, etc. The maximum floor slab thickness was $320 \mathrm{~mm}$. If a larger floor slab thickness is required for structural reasons, it is better to use a waffle slab to reduce the weight.

The third optimization variable, the strength class of concrete, was determined by the technical standards EN 206 and EN 1992-1-1. Concretes from C20/25 to C50/60 are referred to as ordinary concretes and are produced by most concrete plants. Strength classes (from C55/67 up to C100/115) are referred to as high-strength concretes and are only produced by some concrete plants (mostly on request). For comparison, 3 classes of high strength concrete were included in this study, namely C60/70, C70/80, and C80/95.

The feasible set contained a total of 2730 variants $(13 \times 21 \times 10)$. Finding the optimal solution using an exhaustive search would be quite time-consuming. However, it was not necessary to go through this whole set; it was only necessary to go through a part of it according to the currently calculated variant. For example, a column cross-section in the variant of a building with 4 stories and a column spacing of $4 \mathrm{~m}$ could be optimized in the range from $200 \times 200$ to $300 \times 300 \mathrm{~mm}$ (only 3 values). A larger column cross-section is unnecessary for such a small span. Similarly, a floor slab thickness for $4 \mathrm{~m}$ span was optimized in the range of $140-170 \mathrm{~mm}$. A smaller slab thickness was not possible due to deflection 
requirement, and a larger slab thickness would be uneconomical. The number of variables was thus reduced for each variant of the building $(5 \times 4 \times 10)$, which significantly accelerated the calculation.

\subsection{Software Tools}

To find the optimal variant of the load-bearing structure, it was necessary to use a structural analysis software that allowed us to script the modelled structure. For this reason, the structural analysis program RFEM from Dlubal Software s.r.o. was chosen because it includes an additional programmable interface based on Component Object Model (COM) technology. Thanks to this COM interface, the modelled structure could be modified and the calculation could be started again. Therefore, it was possible to create a relatively complex optimization program and fully automate the optimization task.

The optimization program was programmed in Visual Basic for Applications (VBA), which is part of the MS Excel spreadsheet. The combination of VBA and Excel is advantageous for several reasons. Firstly, VBA is designed for writing custom macros, and the VBA editor is already implemented in Excel. Secondly, the optimization results can be saved and further processed directly in Excel, and there is no need to export data from other programs, which is sometimes a problem. Last but not least, the combination has the advantage of high portability without the need to install additional programs.

\subsection{Structural Design}

The structural design was performed by the limit state method. The cross-sectional dimensions of the load-bearing elements (column cross-sections and the floor slabs thicknesses) were optimized on the basis of the ULS-STR requirements (see EN 1990). The columns were designed with regard to the combination of normal force and bending moment, considering the effect of slenderness and second order and geometric imperfections (EN 1992-1-1). The floor slabs were reinforced in terms of bending and punching shear resistances. The serviceability limit state was not verified in detail, but a simplified assessment (on span/effective depth ratios) was used. As such, it was not necessary to calculate the deflections explicitly and nevertheless because the floor slab was sufficiently thick. Therefore, within the economically focused design, the floor slab thickness according to this simplified assessment was reduced by $20 \mathrm{~mm}$, which was a value closer to reality. This study did not perform an exact design of reinforcement; it only performed the calculation of the required area of reinforcement without the design of specific profiles and their distribution. Thanks to this step, the time required for optimization was reduced to less than half.

The structure was loaded according to the standard EN 1991-1-1. The load was divided into individual load cases, from which combinations of actions were subsequently created. The permanent loads included the self-weight of the RC structure, the load of the floor $\left(2 \mathrm{kN} / \mathrm{m}^{2}\right)$, and building envelope load $\left(1.5 \mathrm{kN} / \mathrm{m}\right.$ ). The variable loads included imposed load (offices with $3 \mathrm{kN} / \mathrm{m}^{2}$ ), movable partitions $\left(0.8 \mathrm{kN} / \mathrm{m}^{2}\right)$, snow on a flat roof $\left(0.56 \mathrm{kN} / \mathrm{m}^{2}\right)$, and wind on the entire area of the building, which was automatically generated in RFEM (for the territory of Prague, Czech Republic). Accidental loads, such as earthquakes, were not included because very little or no earthquakes occur in the Czech Republic (like in the most of other regions of Central Europe). Consequently, the load combination was compiled from these load cases. Partial factors of 1.35 for permanent actions and 1.5 for variable actions were used.

The building was founded on a concrete foundation slab, and the used concrete was C30/37. The foundation slab thickness was determined by a preliminary calculation based on the punching shear resistance. The foundation slab in the variants of building with a column spacing of $8 \mathrm{~m}$ was supplemented by RC piles with diameters of 600,900 , and $1200 \mathrm{~mm}$ for 4-story, 8-story, and 12-story buildings, respectively. The length of the piles was $12 \mathrm{~m}$ in all cases, and a load-bearing bedrock was already assumed below this level. The reinforcement of the foundation slabs and piles was not exactly dimensioned, but an estimate of the average reinforcement according to standard conditions was performed. 


\subsection{Construction Costs Assessment}

The construction cost of building is usually stated by a cost estimate that includes list of all building structures and works with associated prices. In our case, the cost estimate contained only the elements of the load-bearing structure because the load-bearing structure was the main interest of this study. The following items were calculated for each element of the load-bearing structure (columns, walls, floor slabs, and foundation slabs):

- $\quad$ Concrete of specific strength class (including transport to the construction site).

- $\quad$ Reinforcement B500b (including transport to the construction site).

- Formwork assembly and disassembly (including temporary support of ceiling).

- Transfer of materials within the construction site.

The cost calculation of the load-bearing structure was based on the national pricing system (CS ÚRS) [21]. This system contains approximately 170,000 items of construction works and materials with detailed descriptions and base prices. The database is used by investors, designers, and building suppliers. Base prices were used for initial cost calculation, and prices were in Czech crowns (CZK) that are converted into Euros at an exchange rate of $26 \mathrm{CZK}$ to 1 Euro.

Associated prices consist of the cost of materials, labor, levies, machinery, sub-delivery, overheads, and profits. Material costs (concrete and reinforcement) are the most dominant part of the total construction costs. Therefore, to have more accurate results, concrete and reinforcement costs were acquired from market investigation and used instead of base prices. Table 1 shows these market prices for all the used concrete strength classes. The price of the B500b reinforcement was set to 21,000 CZK/t, that is, approximately $808 \mathrm{EUR} / \mathrm{t}$.

Table 1. Used concrete mixtures for different strength classes $\left(\mathrm{kg}\right.$ per $\left.\mathrm{m}^{3}\right)$.

\begin{tabular}{ccccccccccc}
\hline Material & C20/25 & C25/30 & C30/37 & C35/45 & C40/50 & C45/55 & C50/60 & C60/75 & C70/85 & C80/95 \\
\hline Cement 42.5 R & & & & 390 & 420 & 450 & 470 & 500 & 530 & 560 \\
Cement 32.5 R & 340 & 370 & 410 & & & & & & & \\
Sand 0/4 & 871 & 853 & 826 & 892 & 877 & 863 & 855 & 837 & 811 & 772 \\
Gravel 4/8 & 361 & 353 & 342 & 369 & 363 & 357 & 354 & 347 & 336 & 320 \\
Gravel 8/16 & 511 & 500 & 484 & 523 & 514 & 506 & 501 & 491 & 475 & 453 \\
Microsilica & - & - & - & - & - & - & - & - & 15 & 40 \\
Superplasticizers & - & - & 1 & 2 & 3 & 4 & 5 & 8 & 12 & 16 \\
$\quad$ Water & 211 & 215 & 221 & 179 & 181 & 180 & 179 & 180 & 180 & 185 \\
\hline Cost $\left(€ / \mathrm{m}^{3}\right)$ & 72.30 & 75.80 & 83.50 & 91.90 & 99.20 & 106.90 & 113.10 & 147.70 & 196.20 & 263.10 \\
\hline
\end{tabular}

\subsection{Environmental Assessment}

An environmental impact of the concrete structure was analyzed using the life cycle assessment method. This method is suitable for the analysis of potential environmental impacts that could be caused during the whole life cycle of products or services. According to ISO 14040 [22] and ISO 14044 [23], this method has four iterative steps. In the first step, the goal and scope of the study are set and the assessed system boundaries and function of product or service are defined. Based on the assessed function, the functional unit is defined to express how the function is fulfilled. The second step is inventory analysis, and in this step, all material and energy inputs and outputs of the described system are analyzed. In the third step, these inputs and outputs are classified into some impact categories and characterized by using characterization factors according to the selected impact assessment method. The fourth step is the interpretation of results, in which the robustness of the study is tested and limitations are described regarding the previous steps [24].

In this study, the potential environmental impacts were analyzed for six reinforced concrete structures in the construction phase. For each structure, the potential environmental impact was compared for 10 variants with different strength classes of the used concrete. The main function 
of a building is to provide usable space in an area. Each of the assessed structures provides different usable spaces with different proportions, and, therefore, the function associated to these structures is not comparable. On the other hand, variants of one structure provide usable spaces with similar proportions so that the environmental impacts among these variants can be compared.

The structures were compared in the design phase so the considered system boundaries included the excavation of raw resources and their processing, the production of products, their transport on the site, and construction and installation processes on the construction site including the transport of materials and products on the site. This scope could be called as "cradle-to-gate." According to EN 15804 A1 [25], this scope includes the part of the life cycle from the A1 module to the A5 module. The considered system boundaries are graphically expressed in Figure 4.

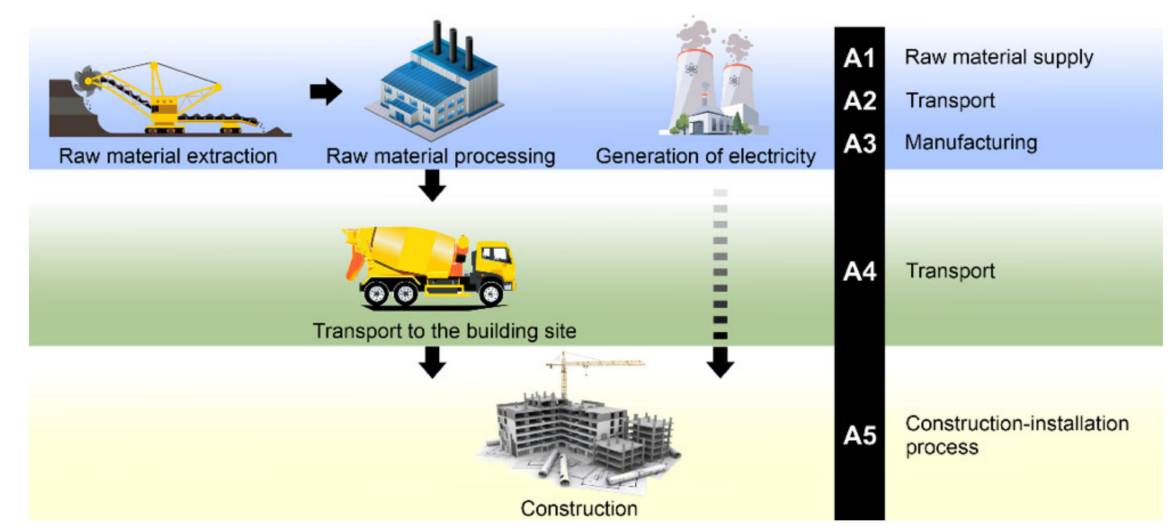

Figure 4. Scheme of boundaries of the assessed system.

The described system boundaries were set regarding the assumption that the lifespan of construction exceeds the lifespan of other parts of the building. This assumption reflects the fact that in case of the right maintenance of a building, the lifespan of concrete core structure differs from the real working life of other parts. Moreover, with this assumption, the results of the study were not influenced by uncertainty, which is caused in other phases of the life cycle of a building such as maintenance, renovation, or removal. Additionally, load-bearing structures in buildings are designed with the same approach to reach the working life of 50 years according to EN 1990. Therefore, it can be assumed that structures with different strength classes have the same design working life.

The considered processes, which were included in the system boundaries, are described in Table 2. Regarding the defined scope, the influence of carbonation was not considered. Similarly, the system boundaries does not include any processes describing the end of life phase of the structures, such as deconstruction, the recycling of concrete, or disposal. The end-of-life phase was not included due to uncertainty, which is affected by different possibilities of the using, reusing, or removing of structures after the expiration of designed working life. Environmental datasets for processes were taken over from the thinkstep database, and environmental modelling was managed in the GaBi software [26]. 
Table 2. Expected processes included within the system boundaries.

\begin{tabular}{|c|c|}
\hline $\begin{array}{l}\text { Considered } \\
\text { Processes }\end{array}$ & Description \\
\hline $\begin{array}{l}\text { Production of } \\
\text { cement I } 42.5 \mathrm{R}\end{array}$ & $\begin{array}{l}\text { The process includes the excavation of primary resources, the production of clinker, } \\
\text { and the grinding of cement. Dataset represents the referential production of cement } \\
\text { in Germany. The cement is marked according to EN 197-1. }\end{array}$ \\
\hline $\begin{array}{l}\text { Production of } \\
\text { cement II } 32.5 \mathrm{R}\end{array}$ & $\begin{array}{l}\text { The process includes the excavation of primary resources, the production of clinker, } \\
\text { and the grinding of cement. Dataset represents the referential production of cement } \\
\text { in Germany. The cement is marked according to EN 197-1. }\end{array}$ \\
\hline Sand production & $\begin{array}{l}\text { Dataset represents the referential technological mix in Germany, which includes wet } \\
\text { and dry excavations. }\end{array}$ \\
\hline Gravel production & $\begin{array}{l}\text { The process includes excavation of gravel, washing, drying, and sorting into fractions. } \\
\text { Dataset represents referential German production. }\end{array}$ \\
\hline $\begin{array}{l}\text { Reinforced } \\
\text { steel production }\end{array}$ & Dataset represents referential European production. \\
\hline $\begin{array}{l}\text { Production } \\
\text { of polycarboxylate } \\
\text { superplasticizers }\end{array}$ & $\begin{array}{l}\text { Dataset represents the referential European production of polycarboxylates } \\
\text { for building purposes. }\end{array}$ \\
\hline $\begin{array}{l}\text { Transport } \\
\text { using truck }\end{array}$ & $\begin{array}{l}\text { The process represents referential transport using a truck in EU-28. Dataset represents } \\
\text { the technological mix of trucks with Euro } 0-6 \text { emission standards. The total weight } \\
\text { of the truck is } 40 \mathrm{t} \text {, and the maximal payload is } 27 \mathrm{t} \text {. The distance was estimated } \\
\text { according to typical Czech conditions. }\end{array}$ \\
\hline Concrete mixing & $\begin{array}{l}\text { The process represents the mixing of concrete in a continual mixing machine that has } \\
\text { an inner volume of } 2.5 \mathrm{~m}^{3} \text {. The power consumption is } 55 \mathrm{~kW} \text {. }\end{array}$ \\
\hline Pumping concrete & $\begin{array}{l}\text { The process represents the use of a pump for concrete mixtures. The pump is placed } \\
\text { on an automobile chassis, and the rate of the pump is } 170 \mathrm{~m}^{3} \text { per hour. }\end{array}$ \\
\hline $\begin{array}{l}\text { Transport on the } \\
\text { building site }\end{array}$ & $\begin{array}{l}\text { The process represents the transport on the building site using a semi-mobile crane. } \\
\text { The power consumption is } 21 \mathrm{~kW} .\end{array}$ \\
\hline $\begin{array}{l}\text { Electricity } \\
\text { production }\end{array}$ & Dataset represents the electricity grid mix in the Czech Republic. \\
\hline
\end{tabular}

For the Inventory analysis, information about material flows was assumed according to calculated amounts of materials for designed structures. Information about the transport and energy consumption of construction processes was assumed according to the ÚRS database. The environmental impacts of concrete mixtures were modelled regarding the concrete recipes mentioned in Table 1. Generic processes for modelling of the excavation of sand and aggregates, production of steel, cement, and superplasticizers were taken from the thinkstep database. Similarly, the processes for modelling of transport of materials come from the same database. The environmental impacts of electricity consumption were modelled using the generic process for the production of electricity in the Czech grid.

The elementary flows, as outputs or inputs of production systems, were characterized according to the ReCiPe method, version 1.08 [27]. This method includes midpoint indicators from the CML method and endpoint indicators from the Eco-Indicator method. Moreover, this method uses three datasets of characterization factors for the distinguishing of following cultural perspectives: individualist (I), hierarchist $(\mathrm{H})$, and egalitarian (E). In this study, the most consensual hierarchist $(\mathrm{H})$ perspective was chosen. This perspective takes the medium time frame into account, so this perspective is suitable for research studies. The midpoint indicators, which were used in this study, are described in the following Table 3. 
Table 3. Description of environmental indicators.

\begin{tabular}{|c|c|c|c|}
\hline Impact Category & Abbreviation & Units & Description of the Indicator \\
\hline $\begin{array}{l}\text { Climate change, } \\
\text { including biogenic } \\
\text { carbon }\end{array}$ & GWP & $\mathrm{kg} \mathrm{CO}_{2}$ eq. & $\begin{array}{l}\text { This indicator describes the potential absorption } \\
\text { of infrared radiation in comparison with the emission } \\
\text { of carbon dioxide as a reference compound and expresses } \\
\text { that as the amount of equivalent of carbon dioxide. }\end{array}$ \\
\hline Fossil depletion & FDP & kg oil eq. & $\begin{array}{l}\text { This indicator describes the consumption of fossil } \\
\text { resources and expresses it as a potential amount of oil } \\
\text { equivalents with the same caloric value as the consumed } \\
\text { fossil resources. }\end{array}$ \\
\hline Metal depletion & MDP & kg Fe eq. & $\begin{array}{l}\text { This indicator describes the consumption of metals due to } \\
\text { the depletion of resources. The depletion is expressed } \\
\text { using the number of kg equivalent iron (Fe). }\end{array}$ \\
\hline $\begin{array}{c}\text { Terrestrial } \\
\text { acidification }\end{array}$ & TAP & $\mathrm{kg} \mathrm{SO}_{2}$ eq. & $\begin{array}{l}\text { This indicator describes the ability of emissions to release } \\
\text { protons }\left(\text { as } \mathrm{H}^{+}\right) \text {. The reference compound for comparison } \\
\text { is sulfur dioxide. }\end{array}$ \\
\hline $\begin{array}{l}\text { Freshwater } \\
\text { eutrophication }\end{array}$ & FEP & kg P eq. & $\begin{array}{l}\text { This indicator describes the potential eutrophication, } \\
\text { which could be caused by emissions od phosphorus and } \\
\text { nitrogen. The reference compound is phosphorus. }\end{array}$ \\
\hline Ozone depletion & ODP & kg CFC-11 eq. & $\begin{array}{l}\text { This indicator describes the potential ability of emissions } \\
\text { to cause stratospheric ozone depletion. The reference } \\
\text { compound is trichlorofluoromethane (CFC-11). }\end{array}$ \\
\hline $\begin{array}{l}\text { Particulate matter } \\
\text { formation }\end{array}$ & PMFP & $\mathrm{kg} \mathrm{PM}_{10}$ eq. & $\begin{array}{c}\text { This indicator describes the impact, which could be caused } \\
\text { by emissions to air. The particles with a diameter smaller } \\
\text { than } 10 \mu \mathrm{m} \text { (PM10) are used as a reference. }\end{array}$ \\
\hline $\begin{array}{l}\text { Photochemical } \\
\text { oxidant } \\
\text { formation }\end{array}$ & POFP & kg NMVOC eq. & $\begin{array}{l}\text { This indicator describes the increase in the level } \\
\text { of tropospheric ozone due to emissions to air. The } \\
\text { reference is the equivalent of non-methanogenic volatile } \\
\text { organic compounds (NMVOC). }\end{array}$ \\
\hline
\end{tabular}

The results of the indicators were normalized and weighted. Normalization is used to express the results of individual compared products as dimensionless values, which can be summarized. The normalized results were calculated by dividing the results of the indicators by normalized contributions for individual indicators. Normalized contributions were used according to the ReCiPe $1.08(\mathrm{H})$ mid-point normalization dataset, which describes world contributions as person equivalents and includes biogenic carbon (ReCiPe $1.08(\mathrm{H})$ mid-point normalization, World, including biogenic carbon (person equivalents)) [28]. Weighing is used for emphasizing the results according to the values for individual categories that are set by a group of experts. The weighted results were calculated by multiplying the normalized results by weighting factors for individual categories. The weighting factors were used according to the thinkstep Life Cycle Impact Assessment Survey (LCIA Survey 2012) for estimating the global weighting factors for the ReCiPe method, version $1.08(\mathrm{H})$, which includes biogenic carbon (person equivalent weighted) (thinkstep LCIA Survey 2012, Global, ReCiPe $1.08(\mathrm{H})$, including biogenic carbon (person equivalent weighted)), and they are available in the Gabi software [26].

\section{Results and Discussion}

The results of the study are divided into three sections due to the large amount of data. The first section shows information about the optimal dimensions of load-bearing elements, including the total amount of concrete and the required reinforcement. The second section deals with construction costs, and the third section evaluates the environmental impacts of the structure.

\subsection{Optimal Dimensions of Load-Bearing Elements}

The optimization results are collected in six tables according to individual variants (Tables 4-9). The optimal dimensions of load-bearing elements and the amount of used concrete and reinforcement 
are given for each strength class of concrete. Core walls are not included because they were not optimized (the walls had a constant thickness of $200 \mathrm{~mm}$, and only the required reinforcement was determined). Foundation construction was designed according to a preliminary design (see Section 2.5).

The variant of building with four stories and a column spacing of $4 \mathrm{~m}$ (Table 5) was structurally the least demanding variant. Except for strength class C20/25, the column cross-section of $0.2 \times 0.2 \mathrm{~m}$ was sufficient. The floor slab thickness was also relatively small, and the use of concrete C40/50 and higher led to a reduction in thickness to a minimum. Therefore, it could be stated that this variant of the building makes sense to design from concrete of low strength (e.g., C20/25 or C25/30). Higher strength concrete would not be fully utilized with this type of structure.

Table 4. Summary of results for variant of building with 4 stories and a column spacing of $8 \mathrm{~m}$.

\begin{tabular}{cccccccc}
\hline \multirow{2}{*}{$\begin{array}{c}\text { Concrete } \\
\text { Class }\end{array}$} & \multicolumn{2}{c}{ Dimensions of Load-Bearing Elements $(\mathbf{m})$} & \multicolumn{2}{c}{ Volume of Concrete $\mathbf{( m}^{\mathbf{3}}$ ) } & Reinforcement Weight $(\mathbf{t})$ \\
\cline { 2 - 8 } & $\begin{array}{c}\text { Column } \\
\text { Cross-Section }\end{array}$ & $\begin{array}{c}\text { Floor } \\
\text { Slab }\end{array}$ & $\begin{array}{c}\text { Foundation } \\
\text { Slab }\end{array}$ & Columns & $\begin{array}{c}\text { Floor } \\
\text { Slabs }\end{array}$ & Columns & $\begin{array}{c}\text { Floor } \\
\text { Slabs }\end{array}$ \\
\hline C30/37 & $0.4 \times 0.4$ & 0.31 & 0.6 & 33.8 & 1334.6 & 3.8 & 39.6 \\
C35/45 & $0.4 \times 0.4$ & 0.28 & 0.6 & 34.1 & 1205.5 & 3.1 & 40.5 \\
C40/50 & $0.35 \times 0.35$ & 0.25 & 0.55 & 25.9 & 1076.3 & 3.2 & 42.8 \\
C45/55 & $0.35 \times 0.35$ & 0.22 & 0.55 & 26.2 & 947.2 & 3.0 & 44.7 \\
C50/60 & $0.35 \times 0.35$ & 0.2 & 0.5 & 26.4 & 861.1 & 2.9 & 47.0 \\
C60/75 & $0.3 \times 0.3$ & 0.19 & 0.45 & 19.0 & 818.0 & 3.0 & 49.2 \\
C70/85 & $0.3 \times 0.3$ & 0.18 & 0.45 & 19.0 & 774.9 & 2.9 & 50.4 \\
C80/95 & $0.3 \times 0.3$ & 0.18 & 0.45 & 19.0 & 774.9 & 2.8 & 49.7 \\
\hline
\end{tabular}

In contrast, the variant of building with four stories and a column spacing of $8 \mathrm{~m}$ (Table 4 ) was quite different. Firstly, concretes of strength classes C20/25 and C25/30 were not suitable because floor slab thickness would be too large due to the requirements for limit states. Secondly, the dimensions of the columns and floor slabs were significantly higher due to double span. This led to a massive increase in the volume of concrete and reinforcement. Thirdly, foundation slab thickness was also larger and was complemented by piles. This represents the tax for greater freedom of interior space.

Table 5. Summary of results for variant of building with 4 stories and a column spacing of $4 \mathrm{~m}$.

\begin{tabular}{|c|c|c|c|c|c|c|c|}
\hline \multirow{2}{*}{$\begin{array}{l}\text { Concrete } \\
\text { Class }\end{array}$} & \multicolumn{3}{|c|}{ Dimensions of Load-Bearing Elements (m) } & \multicolumn{2}{|c|}{ Volume of Concrete $\left(\mathrm{m}^{3}\right)$} & \multicolumn{2}{|c|}{ Reinforcement Weight (t) } \\
\hline & $\begin{array}{c}\text { Column } \\
\text { Cross-Section }\end{array}$ & $\begin{array}{l}\text { Floor } \\
\text { Slab }\end{array}$ & $\begin{array}{l}\text { Foundation } \\
\text { Slab }\end{array}$ & Columns & $\begin{array}{l}\text { Floor } \\
\text { Slabs }\end{array}$ & Columns & $\begin{array}{l}\text { Floor } \\
\text { Slabs }\end{array}$ \\
\hline C20/25 & $0.25 \times 0.25$ & 0.16 & 0.35 & 43.8 & 688.8 & 6.0 & 20.2 \\
\hline $\mathrm{C} 25 / 30$ & $0.2 \times 0.2$ & 0.15 & 0.35 & 34.3 & 645.8 & 6.2 & 21.0 \\
\hline $\mathrm{C} 30 / 37$ & $0.2 \times 0.2$ & 0.14 & 0.35 & 34.4 & 602.7 & 5.7 & 21.6 \\
\hline $\mathrm{C} 35 / 45$ & $0.2 \times 0.2$ & 0.13 & 0.35 & 34.5 & 559.7 & 5.4 & 23.1 \\
\hline $\mathrm{C} 40 / 50$ & $0.2 \times 0.2$ & 0.12 & 0.35 & 34.6 & 516.6 & 5.4 & 24.4 \\
\hline C45/55 & $0.2 \times 0.2$ & 0.12 & 0.35 & 34.6 & 516.6 & 5.4 & 23.9 \\
\hline C50/60 & $0.2 \times 0.2$ & 0.12 & 0.35 & 34.6 & 516.6 & 5.3 & 22.9 \\
\hline C60/75 & $0.2 \times 0.2$ & 0.12 & 0.35 & 34.6 & 516.6 & 5.3 & 21.6 \\
\hline C70/85 & $0.2 \times 0.2$ & 0.12 & 0.35 & 34.6 & 516.6 & 5.3 & 20.8 \\
\hline C80/95 & $0.2 \times 0.2$ & 0.12 & 0.35 & 34.6 & 516.6 & 5.3 & 20.8 \\
\hline
\end{tabular}

The results of the building with eight stories (Tables 6 and 9) were similar to the building with four stories. Nevertheless, the dimensions of the columns and the foundation slab thicknesses were again significantly larger. The floor slab thickness was the same, but the reinforcement ratio increased slightly with the height of the building. This was caused by a stiffness reduction in higher stories/floors due to greater distance from the fixed support (foundation structures). Concretes of higher strength classes were preferred mainly for the variant with a column spacing of $8 \mathrm{~m}$, and, vice versa, the concretes with lower strength were preferred for the variant with a column spacing of $4 \mathrm{~m}$. 
Table 6. Summary of results for variant of building with 8 stories and a column spacing of $8 \mathrm{~m}$.

\begin{tabular}{cccccccc}
\hline \multirow{2}{*}{$\begin{array}{c}\text { Concrete } \\
\text { Class }\end{array}$} & \multicolumn{2}{c}{ Dimensions of Load-Bearing Elements $(\mathbf{m})$} & \multicolumn{2}{c}{ Volume of Concrete $\left.\mathbf{( m}^{\mathbf{3}}\right)$} & \multicolumn{2}{c}{ Reinforcement Weight $(\mathbf{t})$} \\
\cline { 2 - 8 } & $\begin{array}{c}\text { Column } \\
\text { Cross-Section }\end{array}$ & $\begin{array}{c}\text { Floor } \\
\text { Slab }\end{array}$ & $\begin{array}{c}\text { Foundation } \\
\text { Slab }\end{array}$ & Columns & $\begin{array}{c}\text { Floor } \\
\text { Slabs }\end{array}$ & Columns & $\begin{array}{c}\text { Floor } \\
\text { Slabs }\end{array}$ \\
\hline C30/37 & $0.55 \times 0.55$ & 0.31 & 0.75 & 109.4 & 2662.8 & 11.0 & 81.9 \\
C35/45 & $0.55 \times 0.55$ & 0.28 & 0.7 & 110.5 & 2405.1 & 8.2 & 83.7 \\
C40/50 & $0.5 \times 0.5$ & 0.25 & 0.7 & 89.7 & 2147.4 & 7.8 & 87.8 \\
C45/55 & $0.5 \times 0.5$ & 0.22 & 0.65 & 90.6 & 1889.7 & 6.5 & 92.0 \\
C50/60 & $0.45 \times 0.45$ & 0.20 & 0.6 & 71.3 & 1717.9 & 6.7 & 98.7 \\
C60/75 & $0.45 \times 0.45$ & 0.19 & 0.6 & 71.5 & 1632.0 & 5.8 & 100.5 \\
C70/85 & $0.45 \times 0.45$ & 0.18 & 0.6 & 71.8 & 1546.1 & 5.8 & 102.6 \\
C80/95 & $0.45 \times 0.45$ & 0.18 & 0.6 & 71.8 & 1546.1 & 5.8 & 101.2 \\
\hline
\end{tabular}

Table 7. Summary of results for variant of building with 12 stories and a column spacing of $4 \mathrm{~m}$.

\begin{tabular}{cccccccc}
\hline \multirow{2}{*}{$\begin{array}{c}\text { Concrete } \\
\text { Class }\end{array}$} & \multicolumn{2}{c}{ Dimensions of Load-Bearing Elements $(\mathbf{m})$} & \multicolumn{2}{c}{ Volume of Concrete $\left.\mathbf{( m}^{\mathbf{3}}\right)$} & \multicolumn{2}{c}{ Reinforcement Weight $(\mathbf{t})$} \\
\cline { 2 - 8 } & $\begin{array}{c}\text { Column } \\
\text { Cross-Section }\end{array}$ & $\begin{array}{c}\text { Floor } \\
\text { Slab }\end{array}$ & $\begin{array}{c}\text { Foundation } \\
\text { Slab }\end{array}$ & Columns & $\begin{array}{c}\text { Floor } \\
\text { Slabs }\end{array}$ & Columns & $\begin{array}{c}\text { Floor } \\
\text { Slabs }\end{array}$ \\
\hline C20/25 & $0.45 \times 0.45$ & 0.16 & 0.6 & 289.3 & 2059.8 & 22.3 & 68.0 \\
C25/30 & $0.4 \times 0.4$ & 0.15 & 0.6 & 220.6 & 1931.1 & 22.1 & 72.1 \\
C30/37 & $0.4 \times 0.4$ & 0.14 & 0.6 & 221.3 & 1802.4 & 19.4 & 73.8 \\
C35/45 & $0.4 \times 0.4$ & 0.13 & 0.6 & 222.0 & 1673.6 & 18.9 & 77.0 \\
C40/50 & $0.35 \times 0.35$ & 0.12 & 0.6 & 170.8 & 1544.9 & 18.5 & 84.0 \\
C45/55 & $0.35 \times 0.35$ & 0.12 & 0.6 & 170.8 & 1544.9 & 18.0 & 83.5 \\
C50/60 & $0.35 \times 0.35$ & 0.12 & 0.6 & 170.8 & 1544.9 & 17.6 & 80.3 \\
C60/75 & $0.3 \times 0.3$ & 0.12 & 0.6 & 135.2 & 1544.9 & 17.4 & 81.7 \\
C70/85 & $0.3 \times 0.3$ & 0.12 & 0.6 & 135.2 & 1544.9 & 16.8 & 75.1 \\
C80/95 & $0.3 \times 0.3$ & 0.12 & 0.6 & 135.2 & 1544.9 & 16.8 & 73.2 \\
\hline
\end{tabular}

Likewise, the results of the building with 12 stories (Tables 7 and 8) were similar to the previous variants. The main difference was again in the dimensions of the columns and the foundation slab. The cross-sections of the columns were relatively massive and showed a disadvantage when concrete with low strength was used for a multi-story building. At least for columns on the lowest floors of the building, it would certainly be much better to use concrete of higher strength classes. An increase of reinforcement amount in floor slabs due to the stiffness reduction in the highest stories was again evident.

Table 8. Summary of results for variant of building with 12 stories and a column spacing of $8 \mathrm{~m}$.

\begin{tabular}{|c|c|c|c|c|c|c|c|}
\hline \multirow{2}{*}{$\begin{array}{l}\text { Concrete } \\
\text { Class }\end{array}$} & \multicolumn{3}{|c|}{ Dimensions of Load-Bearing Elements (m) } & \multicolumn{2}{|c|}{ Volume of Concrete $\left(\mathrm{m}^{3}\right)$} & \multicolumn{2}{|c|}{ Reinforcement Weight (t) } \\
\hline & $\begin{array}{c}\text { Column } \\
\text { Cross-Section }\end{array}$ & $\begin{array}{l}\text { Floor } \\
\text { Slab }\end{array}$ & $\begin{array}{c}\text { Foundation } \\
\text { Slab }\end{array}$ & Columns & $\begin{array}{l}\text { Floor } \\
\text { Slabs }\end{array}$ & Columns & $\begin{array}{l}\text { Floor } \\
\text { Slabs }\end{array}$ \\
\hline $\mathrm{C} 30 / 37$ & $0.75 \times 0.75$ & 0.31 & 0.8 & 285.5 & 3990.9 & 17.3 & 134.4 \\
\hline $\mathrm{C} 35 / 45$ & $0.65 \times 0.65$ & 0.28 & 0.7 & 205.1 & 3604.7 & 17.0 & 142.5 \\
\hline $\mathrm{C} 40 / 50$ & $0.6 \times 0.6$ & 0.25 & 0.65 & 170.5 & 3218.5 & 15.7 & 150.0 \\
\hline $\mathrm{C} 45 / 55$ & $0.55 \times 0.55$ & 0.22 & 0.6 & 138.9 & 2832.3 & 15.5 & 160.8 \\
\hline C50/60 & $0.55 \times 0.55$ & 0.20 & 0.55 & 139.8 & 2574.8 & 12.6 & 168.9 \\
\hline $\mathrm{C} 60 / 75$ & $0.55 \times 0.55$ & 0.19 & 0.55 & 140.3 & 2446.1 & 10.7 & 172.5 \\
\hline C70/85 & $0.55 \times 0.55$ & 0.18 & 0.5 & 140.7 & 2317.3 & 10.6 & 176.7 \\
\hline $\mathrm{C} 80 / 95$ & $0.55 \times 0.55$ & 0.18 & 0.5 & 140.7 & 2317.3 & 10.6 & 174.7 \\
\hline
\end{tabular}


Table 9. Summary of results for variant of building with 8 stories and a column spacing of $4 \mathrm{~m}$.

\begin{tabular}{cccccccc}
\hline \multirow{2}{*}{$\begin{array}{c}\text { Concrete } \\
\text { Class }\end{array}$} & \multicolumn{2}{c}{ Dimensions of Load-Bearing Elements $(\mathbf{m})$} & \multicolumn{2}{c}{ Volume of Concrete $\left.\mathbf{( m}^{\mathbf{3}}\right)$} & \multicolumn{2}{c}{ Reinforcement Weight $(\mathbf{t})$} \\
\cline { 2 - 8 } & $\begin{array}{c}\text { Column } \\
\text { Cross-Section }\end{array}$ & $\begin{array}{c}\text { Floor } \\
\text { Slab }\end{array}$ & $\begin{array}{c}\text { Foundation } \\
\text { Slab }\end{array}$ & Columns & $\begin{array}{c}\text { Floor } \\
\text { Slabs }\end{array}$ & Columns & $\begin{array}{c}\text { Floor } \\
\text { Slabs }\end{array}$ \\
\hline C20/25 & $0.35 \times 0.35$ & 0.16 & 0.5 & 134.5 & 1374.3 & 13.7 & 43.4 \\
C25/30 & $0.3 \times 0.3$ & 0.15 & 0.5 & 99.6 & 1288.4 & 14.3 & 46.4 \\
C30/37 & $0.3 \times 0.3$ & 0.14 & 0.5 & 99.9 & 1202.5 & 12.1 & 47.5 \\
C35/45 & $0.3 \times 0.3$ & 0.13 & 0.5 & 100.2 & 1116.7 & 11.6 & 50.3 \\
C40/50 & $0.25 \times 0.25$ & 0.12 & 0.5 & 78.9 & 1030.8 & 12.0 & 54.0 \\
C45/55 & $0.25 \times 0.25$ & 0.12 & 0.5 & 78.9 & 1030.8 & 11.3 & 53.2 \\
C50/60 & $0.25 \times 0.25$ & 0.12 & 0.5 & 78.9 & 1030.8 & 11.0 & 51.3 \\
C60/75 & $0.2 \times 0.2$ & 0.12 & 0.5 & 69.2 & 1030.8 & 11.4 & 50.0 \\
C70/85 & $0.2 \times 0.2$ & 0.12 & 0.5 & 69.2 & 1030.8 & 10.7 & 46.7 \\
C80/95 & $0.2 \times 0.2$ & 0.12 & 0.5 & 69.2 & 1030.8 & 10.6 & 46.3 \\
\hline
\end{tabular}

In general, it was evident that most concrete and reinforcement is consumed in the floor slabs. On the contrary, the amount of concrete and reinforcement required for the production of columns was minimal. The volume of concrete for columns was only $2.5-14 \%$ of the volume of concrete of floor slabs in all variants. It follows that the optimization of floor slabs is much more important than the optimization of columns [20]. For example, lightening floor slabs has the potential to reduce the volume of concrete, thus saving construction cost and reducing environmental impacts [29].

If we compare building variants with 4,8 , and 12 stories, we can see that the volume of concrete used for floor slabs increased linearly. In the case of columns, this trend did not apply because the column cross-section gradually increased with more stories (this trend was strongly exponential). Regarding reinforcement, the situation was similar. However, in the case of floor slabs, the weight of the reinforcement did not increase linearly, but it was somewhat faster (consequence of the stiffness reduction); conversely, in the case of columns, the increase of reinforcement weight was slower. These trends were observable for both column spacing, but they were more significantly for a column spacing of $8 \mathrm{~m}$. The different nature of trends for floor slabs and columns indicates the possibility of using a different strength class of concrete. Here is an opportunity for future optimization that could significantly increase the efficiency of the supporting structure.

\subsection{Construction Costs}

The construction cost for each variant was calculated using the cost estimate (see Section 2.6). The results are summarized on the charts in Figure 5 (costs are without VAT). This figure shows differences in the construction costs for each variant. The number of stories and the column spacing significantly affected the final costs of the load-bearing structure. Within the same variant, the differences in costs were not so high, but, even so, the right choice of the strength class of concrete could save considerable funds. In general, the construction cost was found to vary more for variants with a column spacing of $8 \mathrm{~m}$, while variants with a column spacing of $4 \mathrm{~m}$ were almost equivalent for ordinary concretes. This was due to the different stresses in the load-bearing structures and, consequently, different amounts of concrete and reinforcement (see Section 3.1). 


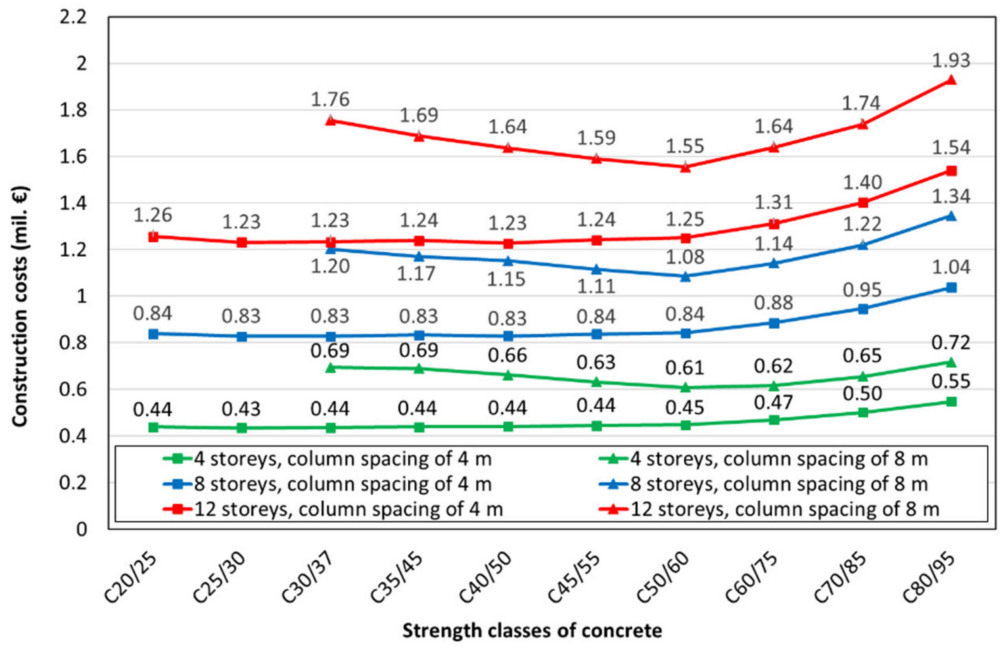

Figure 5. Construction costs of load-bearing structures.

The special group were high-strength concretes (C60/75, C70/85, and C80/95), which were the most expensive choice in all variants. It is true that the use of high-strength concretes leads to a reduction in the dimensions of the load-bearing elements and, consequently, to a reduction in the amount of concrete. However, these savings were not significant enough to offset the high cost of these concretes (see Table 1). In addition, only concrete, not reinforcement, was saved. The main reason was that reducing the cross-section also means reducing the lever arm of internal forces between the concrete and the reinforcement, and this must be compensated for by increased stresses in both materials. As a result, the required amount of reinforcement becomes larger.

An interesting comparison is the relation of the construction costs and the usable area of the building. Increasing the number of stories means higher construction costs but also more usable area. On the other hand, increasing the column spacing will not bring more usable area, but its value will certainly increase due to higher variability of interior layout. However, what is the price per $1 \mathrm{~m}^{2}$ of usable area? The answer is provided by the charts in Figure 6. As we can see, the higher number of stories had a positive effect on the price per $\mathrm{m}^{2}$. This was due to the foundation structure, which forms a significant part of the total cost of a load-bearing structure. In other words, a multi-story building has a cheaper foundation per $\mathrm{m}^{2}$ of usable area than a low-story building. If we included the land sale price, the cost savings would be even greater. However, it was not included due to its better variability.

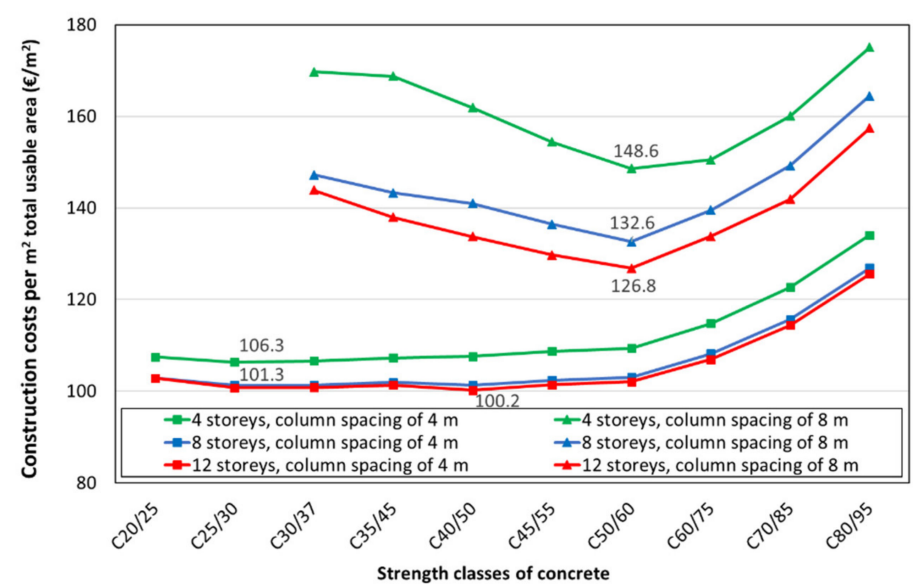

Figure 6. Construction costs of load-bearing structures per $\mathrm{m}^{2}$ of usable area. 


\subsection{Environmental Impacts}

The results of the environmental assessment are organized into three sections according to the number of floors of the building. In each section, the results are presented for structures with different strength classes of concrete. These structures with different strength classes are compared using normalized results, which are summarized and graphically expressed. After normalization, the results of ozone depletion were too low for comparison, and, therefore, this category is not included in figures.

\subsubsection{Building with 4 Stories}

The results of the environmental impacts of building variant with four stories and a column spacing of $4 \mathrm{~m}$ are collected in Table A1 in Appendix A. In most categories, it was evident that the environmental impacts increased with the higher strength class of concrete. The lowest impact was caused by the concrete of strength class $\mathrm{C} 20 / 25$, and the highest impact was by the concrete of strength class C80/95. One exception was the impact of the concrete class C60/75 in the metal depletion category, which was lower than the impacts of C50/60 and C70/85.

The metal depletion indicator significantly affected the total impact of the compared buildings in this study. The environmental impact in this category was strongly influenced by the amount of steel reinforcement, as well as by the consumption of cement. The amount of steel reinforcement for the concrete classes from C40/50 to C80/95 was decreasing because the floor slab thickness for these classes was equal to the minimal value $(120 \mathrm{~mm})$. On the other hand, the higher strength class contains a higher amount of cement (see Table A1), and the production of cement causes an impact in the metal depletion category. Moreover, some deposits contain more minerals, and, thus, an excavation of one mineral several minerals could be depleted, too. Therefore, the consumption of metals was assessed together with the consumption of their deposits, and it is described using kg equivalent iron $(\mathrm{Fe})$ as a reference [27]. Among the mentioned classes, the lowest impact was caused by using C60/75, which contains a low amount of steel reinforcement and a lower amount of cement than the higher classes.

The significant environmental impact in the climate change category was caused by the production of concrete, which includes the production of materials for concrete mixture and the consumption of energy for the mixing, transport, and pumping of concrete. Therefore, the C80/95 class had the biggest impact in this category, and the impact decreased with the lower classes. The share of impact, which is caused by the process of concrete production, was $85 \%$ for the C20/25 class and $91 \%$ for C80/95. Meanwhile, the production of cement for concrete mixture in the case of the C20/25 class created $96 \%$ of the impact of concrete production.

The total environmental impact increased with the higher strength class, as shown in Figure 7 , where the sum of the normalized results for each variant of building with four stories and a column spacing of $4 \mathrm{~m}$ is graphically expressed. The metal depletion category was the category with the most significant influence on the impact. The other significant impact was in the category of climate change, fossil depletion, and particulate matter formation. Additionally, the impact in the freshwater ecotoxicity category increased with the higher concrete classes. The impact in this category was mostly influenced by the added amount of superplasticizers. 


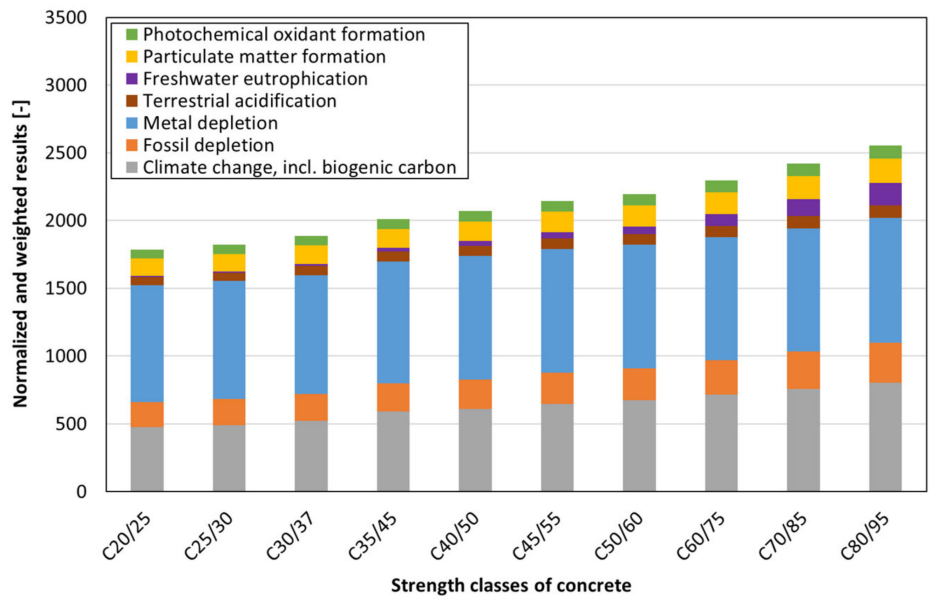

Figure 7. Normalized and weighted results of environmental impacts for buildings with 4 stories and a column spacing of $4 \mathrm{~m}$ (normalized according to ReCiPe 1.08, weighting according to thinkstep LCIA Survey 2012).

The results of environmental impacts for variants of building with four stories and a column spacing of $8 \mathrm{~m}$ are in Table A2 in Appendix A. Compared with variants with a column spacing of $4 \mathrm{~m}$, there was no evident trend of increasing impact. Additionally, no trend was observed among the normalized and or weighted results, which are shown in Figure 8. The C35/45 class reached the highest normalized impact, and the C60/75 class had the lowest sum of the normalized and weighted results. The biggest share of the normalized and weighted result was affected by the impact in the climate change and metal depletion categories. The C60/75 class more effectively used the potential of higher strength of concrete. Meanwhile, higher classes in the variant of the building with a column spacing of $4 \mathrm{~m}$ were used in unnecessarily big amounts so this concrete could not be used effectively.

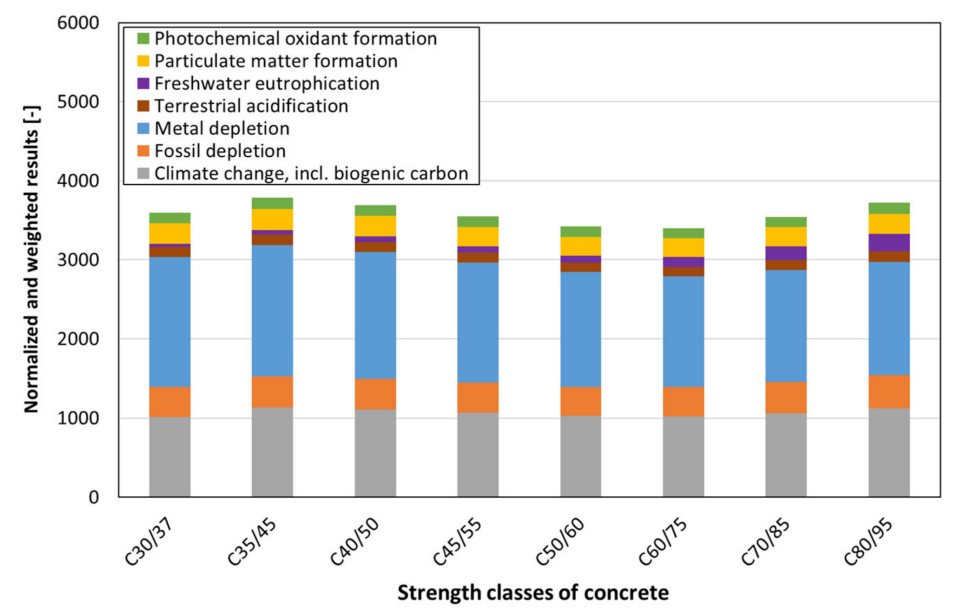

Figure 8. Normalized and weighted results of environmental impacts for buildings with 4 stories and a column spacing of $8 \mathrm{~m}$ (normalized according to ReCiPe 1.08, weighting according to thinkstep LCIA Survey 2012).

\subsubsection{Building with 8 Stories}

In most categories, the impact increased with a higher class for each variant of the buildings with eight stories and a column spacing of $4 \mathrm{~m}$ (see Table A3 in Appendix A). However, the impact in the metal depletion category did not have this trend. In the case of the C50/60 and C70/85 classes, a lower impact was reached due to the lower amount of the used steel reinforcement. However, the C30/37 class sustained an increase in this category due to two factors. The first factor was the lower 
class of concrete with a lower portion of cement in the mixture, which led to a lower impact even with a bigger amount of concrete. The second factor was the less amount of reinforcement (157.9 $t)$ in comparison with the C20/25 class (159.1 t).

In the case of the C30/37 class, the impact of the amount of reinforcement created in the metal depletion category was $93.2 \%$, and it was higher than the impact caused by the amount of cement $(6.7 \%)$. However, the production of concrete for the variant with the C30/37 class caused an impact of $6311 \mathrm{~kg}$ Fe equivalents, whereas for the C25/30 class, the impact was $6913 \mathrm{~kg}$ Fe equivalents. This difference showed that use of a smaller amount of concrete with a higher portion of cement could be more suitable than the utilization of a bigger amount of concrete that is made from a concrete mixture with a lower cement portion for some applications. Despite this partial effect, the sum of the normalized and weighted results increased with a higher strength class (see Figure 9).

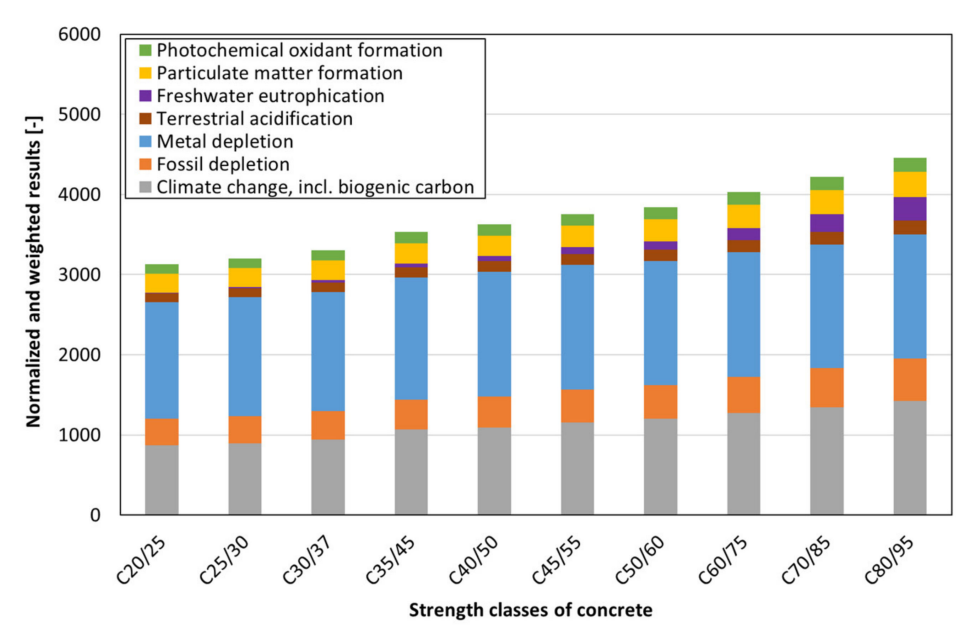

Figure 9. Normalized and weighted results of environmental impacts for buildings with 8 stories and a column spacing of $4 \mathrm{~m}$ (normalized according to ReCiPe 1.08, weighting according to thinkstep LCIA Survey 2012).

In parallel to the impacts of the building with four stories, the environmental impacts of variants with eight stories and a column spacing of $8 \mathrm{~m}$ had no evident trend of increasing impacts (see Table A4 in Appendix A). The C50/60 class had the second smallest impact for this variant in the climate change category, and this class also had the lowest impact in the metal depletion category. The sum of the normalized and weighted results for each class is shown in Figure 10. The C80/95 class caused the biggest total impact, due to the impact in the fossil depletion category. Likewise, the lowest total impact was obtained by using the C50/60 class. 


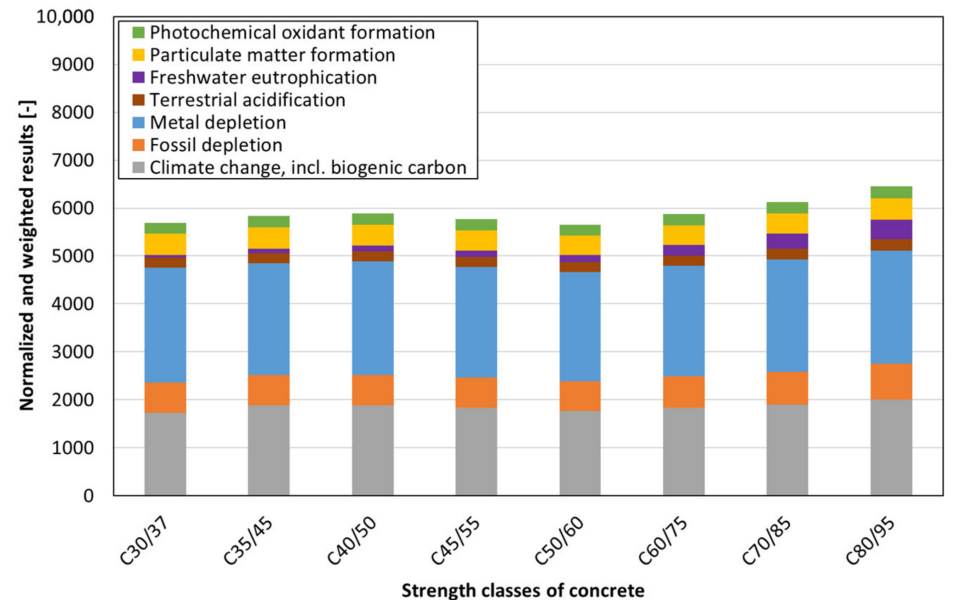

Figure 10. Normalized and weighted results of environmental impacts for buildings with 8 stories and a column spacing of $8 \mathrm{~m}$ (normalized according to ReCiPe 1.08, weighting according to thinkstep LCIA Survey 2012).

\subsubsection{Building with 12 Stories}

As in buildings with four and eight stories, there was a lower impact in the metal depletion category for the C50/60 and C70/85 classes, which were used for the building with 12 stories and a column spacing of $4 \mathrm{~m}$ (see Table A5 in Appendix A). However, according to Figure 11, the sum of normalized and weighted results confirmed the trend of the increasing impacts with a higher class.

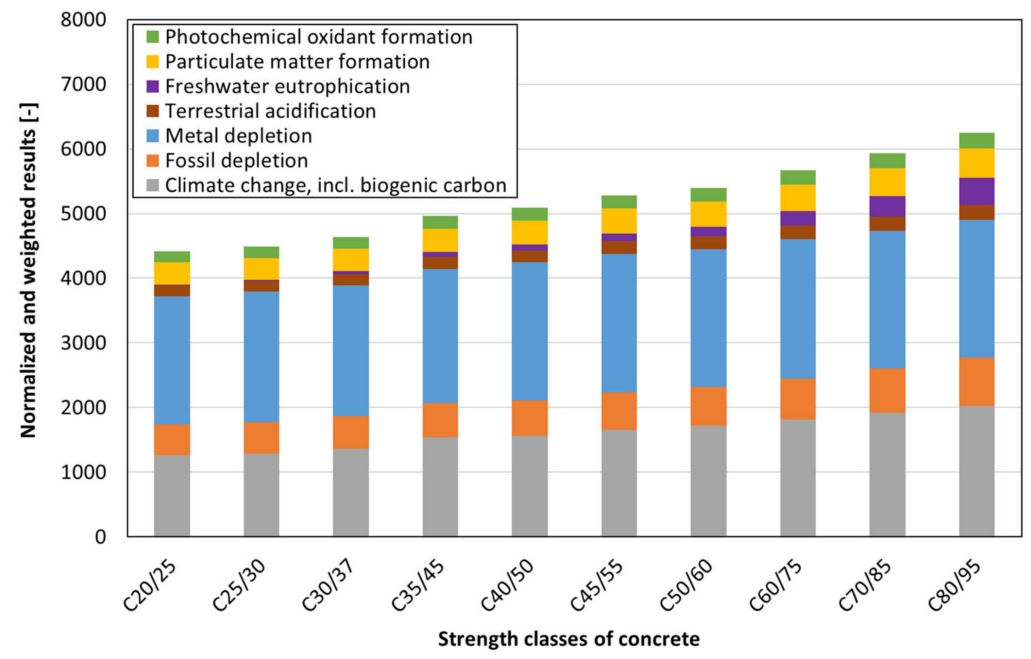

Figure 11. Normalized and weighted results of environmental impacts for buildings with 12 stories and a column spacing of $4 \mathrm{~m}$ (normalized according to ReCiPe 1.08, weighting according to thinkstep LCIA Survey 2012).

The environmental impacts for the building with 12 stories and a column spacing of $8 \mathrm{~m}$ are shown in Table A6 in Appendix A. In comparison with the previously mentioned variants, the results confirmed that the C50/60 class had the lowest impact among other classes for this building category (see Figure 12). 


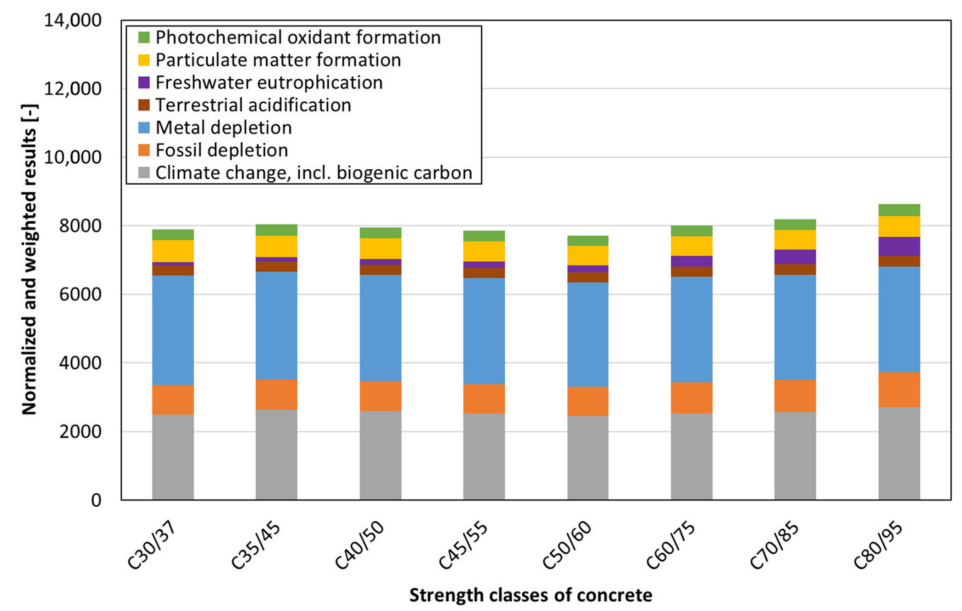

Figure 12. Normalized and weighted results of environmental impacts for buildings with 12 stories and a column spacing of $8 \mathrm{~m}$ (normalized according to ReCiPe 1.08, weighting according to thinkstep LCIA Survey 2012).

Similar to what is seen in Section 3.2, the environmental impact was related to the $1 \mathrm{~m}^{2}$ of the usable area. The climate change potential was used for this comparison because it forms a significant part of the total impact and is also one of the most monitored indicators today. As for cost assessment, the same conclusion can be taken from Figure 13. For variants with a column spacing of $4 \mathrm{~m}$, the smallest impacts were caused by variants of building with 12 stories. For variants with this column spacing, the trend of the increasing impacts with higher concrete class was evident. Among the variants with a column spacing of $8 \mathrm{~m}$, the 12-story buildings had better results, and the C50/60 class, especially, had the smallest impact; thus, no trend was observed. When compared to $1 \mathrm{~m}^{2}$, the building with more stories had a lower environmental impact than the same variant with a smaller number of stories. The difference among buildings with 4,8 , and 12 stories was influenced by the environmental impact of foundation structure, which was connected to a bigger usable area in case of buildings with more stories.

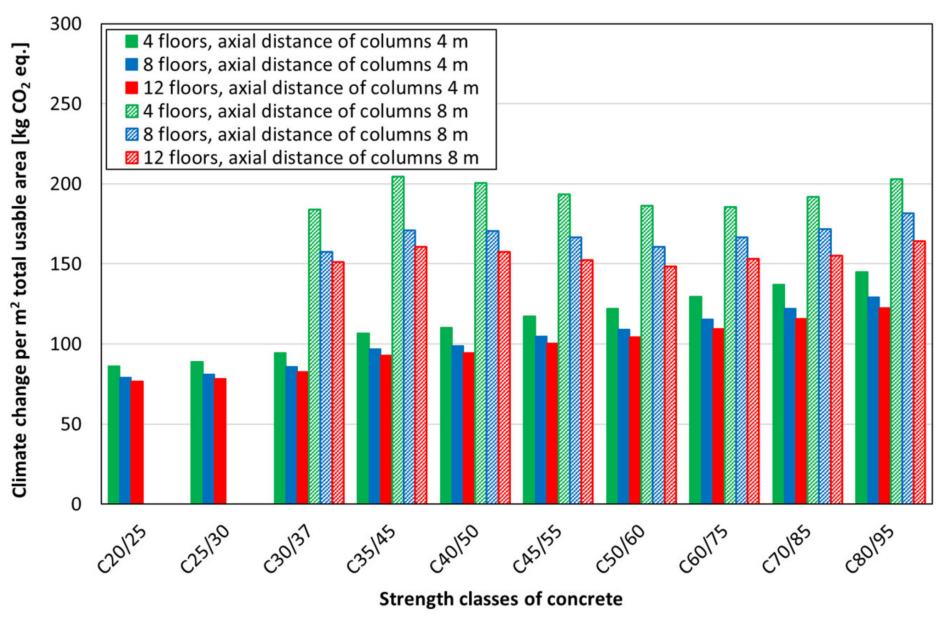

Figure 13. Comparison of climate change indicator per $1 \mathrm{~m}^{2}$ total usable area.

\section{Conclusions}

This case study dealt with the optimization of load-bearing RC building structures. In total, six different variants of the load-bearing building structures were optimized (three height variants and two span variants) in terms of the construction costs and environmental impacts of the building. The results of these case studies produced following findings: 
- Floor slabs represent the most of the mass of the load-bearing building structures, and by optimizing them, it is possible to achieve the highest savings.

- Variants of the load-bearing building structures with a column spacing of $4 \mathrm{~m}$ make sense to design only from concrete of lower strength classes (e.g., C20/25 and C25/30). When using higher strength concrete, the environmental impacts especially increase due to higher cement consumption.

- Variants of the load-bearing building structures with a column spacing $8 \mathrm{~m}$ are best designed from a concrete of strength class C50/60, which has the lowest construction costs and environmental impact.

- By recalculating the construction costs and environmental impacts per $\mathrm{m}^{2}$ of usable area, it is advantageous to design a building with more stories. This is due to the foundation structure, which is the most expensive for a building with less stories.

The optimization of a load-bearing structure can be performed on any type of building and with various number of optimization variables. This study had only three optimization variables, but their number could be easily increased by new parameters. For example, it would be interesting to optimize the degree of lightening of floor slabs or use a different concrete class for the various load-bearing elements (columns $\times$ slabs, etc.). It can be assumed that, in both cases, the optimization efficiency would be significantly increased.

The presented case study showed the possibilities of the multi-criteria optimization of a load-bearing building structure, not only from a structural point of view but also from the economic and environmental points of view. The right choice of strength class of concrete can save significant funds and reduce the environmental impact of construction. The optimization process, as outlined in this paper, could be adapted and performed to most RC structures. Nevertheless, the presented conclusions correspond to this specific construction of the RC building structure used in a case study and may not be generalized to other RC structures. However, the results of the study show certain trends and patterns that can also be used in the design of other reinforced concrete structures. The results also point to the possibility of using concretes of higher strength classes (C40/50, $C 45 / 50$, and C50/60) that are often neglected. Their use has proven to be very advantageous, both in terms of construction costs and environmental impact.

Author Contributions: Conceptualization, M.Ž.; Methodology, M.Ž. and J.P.; Software, M.Ž.; Supervision, M.T., V.K. and P.H.; Validation, M.T.; Writing-original draft, M.Ž. and J.P. All authors have read and agreed to the published version of the manuscript.

Funding: This research received no external funding.

Acknowledgments: This work was supported by the Ministry of Education, Youth and Sports within National Sustainability Programme I, project No. LO1605 and from the grant of Specific university research-grant No A1_FTOP_2020_004. This work was also supported by the institutional support of University of Chemistry and Technology Prague with an innovative and additive manufacturing technology project-new technological solutions for 3D printing of metals and composite materials, reg. no. CZ.02.1.01/0.0/0.0/17_049/0008407 financed by Structural Founds of Europe Union. The article was prepared as part of the doctoral thesis of Michal Ženíšek.

Conflicts of Interest: The authors declare no conflict of interest. 


\section{Appendix A}

Table A1. Variant with 4 stories and a column spacing of $4 \mathrm{~m}$.

\begin{tabular}{|c|c|c|c|c|c|c|c|c|}
\hline Concrete Class & $\begin{array}{c}\text { GWP } \\
{\left[\mathrm{kg} \mathrm{CO}_{2} \text { eq. }\right]}\end{array}$ & $\begin{array}{c}\text { FDP } \\
\text { [kg oil eq.] }\end{array}$ & $\begin{array}{c}\text { MDP } \\
\text { [kg Fe eq.] }\end{array}$ & $\begin{array}{c}\text { TAP } \\
{\left[\mathrm{kg} \mathrm{SO} \mathrm{S}_{2} \text { eq. }\right]}\end{array}$ & $\begin{array}{c}\text { FEP } \\
{[\text { kg P eq.] }}\end{array}$ & $\begin{array}{c}\text { ODP } \\
\text { [g CFC-11 eq.] }\end{array}$ & 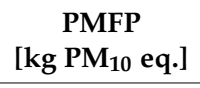 & $\begin{array}{c}\text { POFP } \\
{[\mathrm{kg} \text { NMVOC eq. }]}\end{array}$ \\
\hline C20/25 & 351,553 & 34,361 & 59,814 & 385 & 0.3 & 0.0 & 274 & 488 \\
\hline C25/30 & 364,080 & 35,019 & 60,590 & 394 & 0.3 & 0.0 & 278 & 500 \\
\hline С $30 / 37$ & 385,898 & 36,745 & 60,973 & 411 & 0.8 & 0.1 & 288 & 522 \\
\hline C $35 / 45$ & 436,369 & 38,893 & 62,416 & 446 & 1.2 & 0.1 & 298 & 568 \\
\hline $\mathrm{C} 40 / 50$ & 451,244 & 40,235 & 63,417 & 459 & 1.6 & 0.2 & 304 & 584 \\
\hline C45/55 & 479,691 & 42,249 & 63,535 & 481 & 2.1 & 0.3 & 319 & 614 \\
\hline C50/60 & 498,718 & 43,711 & 63,208 & 497 & 2.5 & 0.3 & 329 & 634 \\
\hline C60/75 & 529,240 & 46,920 & 63,037 & 525 & 3.8 & 0.5 & 346 & 669 \\
\hline C70/85 & 561,192 & 50,836 & 63,239 & 557 & 5.5 & 0.8 & 364 & 708 \\
\hline C80/95 & 593,541 & 54,864 & 64,002 & 591 & 7.2 & 1.1 & 382 & 747 \\
\hline
\end{tabular}

Table A2. Variant with 4 stories and a column spacing of $8 \mathrm{~m}$.

\begin{tabular}{|c|c|c|c|c|c|c|c|c|}
\hline Concrete Class & $\begin{array}{c}\text { GWP } \\
{\left[\mathrm{kg} \mathrm{CO}_{2} \text { eq. }\right]}\end{array}$ & $\begin{array}{c}\text { FDP } \\
\text { [kg oil eq.] }\end{array}$ & $\begin{array}{c}\text { MDP } \\
\text { [kg Fe eq.] }\end{array}$ & $\begin{array}{c}\text { TAP } \\
{\left[\mathrm{kg} \mathrm{SO} \mathrm{O}_{2} \text { eq.] }\right.}\end{array}$ & $\begin{array}{c}\text { FEP } \\
{[\text { kg P eq.] }}\end{array}$ & $\begin{array}{c}\text { ODP } \\
\text { [g CFC-11 eq.] }\end{array}$ & $\begin{array}{c}\text { PMFP } \\
{\left[\mathrm{kg} \text { PM }_{10} \text { eq.] }\right.}\end{array}$ & $\begin{array}{c}\text { POFP } \\
{[\mathrm{kg} \text { NMVOC eq.] }}\end{array}$ \\
\hline C $30 / 37$ & 752,552 & 70,010 & 114,164 & 789 & 1.5 & 0.1 & 562 & 1012 \\
\hline C $35 / 45$ & 836,399 & 73,012 & 115,533 & 842 & 2.4 & 0.3 & 571 & 1083 \\
\hline C40/50 & 819,875 & 71,684 & 111,320 & 822 & 3.0 & 0.4 & 552 & 1055 \\
\hline C45/55 & 791,573 & 69,280 & 105,589 & 791 & 3.4 & 0.5 & 527 & 1012 \\
\hline $\mathrm{C} 50 / 60$ & 761,937 & 67,117 & 101,044 & 761 & 3.8 & 0.5 & 504 & 973 \\
\hline C60/75 & 758,889 & 68,093 & 97,188 & 759 & 5.4 & 0.8 & 497 & 966 \\
\hline C70/85 & 785,696 & 72,573 & 98,604 & 792 & 7.6 & 1.1 & 511 & 1000 \\
\hline C80/95 & 830,164 & 78,043 & 99,148 & 837 & 10.0 & 1.5 & 535 & 1054 \\
\hline
\end{tabular}


Table A3. Variant with 8 stories and a column spacing of $4 \mathrm{~m}$.

\begin{tabular}{|c|c|c|c|c|c|c|c|c|}
\hline Concrete Class & $\begin{array}{c}\text { GWP } \\
{\left[\mathrm{kg} \mathrm{CO}{ }_{2} \text { eq.] }\right.}\end{array}$ & $\begin{array}{c}\text { FDP } \\
\text { [kg oil eq.] }\end{array}$ & $\begin{array}{c}\text { MDP } \\
\text { [kg Fe eq.] }\end{array}$ & $\begin{array}{c}\text { TAP } \\
{\left[\mathrm{kg} \mathrm{SO}{ }_{2} \text { eq. }\right]}\end{array}$ & $\begin{array}{c}\text { FEP } \\
{[\mathrm{kg} P \text { eq. }]}\end{array}$ & $\begin{array}{c}\text { ODP } \\
\text { [g CFC-11 eq.] }\end{array}$ & $\begin{array}{c}\text { PMFP } \\
\text { [kg } \text { PM }_{10} \text { eq.] }\end{array}$ & $\begin{array}{c}\text { POFP } \\
{[\mathrm{kg} \text { NMVOC eq.] }}\end{array}$ \\
\hline C20/25 & 644,030 & 61,558 & 100,813 & 695 & 0.6 & 0.0 & 501 & 886 \\
\hline C25/30 & 662,061 & 62,603 & 103,210 & 708 & 0.6 & 0.0 & 505 & 902 \\
\hline C30/37 & 699,521 & 65,465 & 103,130 & 737 & 1.4 & 0.1 & 522 & 939 \\
\hline C $35 / 45$ & 789,476 & 69,259 & 105,821 & 798 & 2.2 & 0.3 & 539 & 1021 \\
\hline $\mathrm{C} 40 / 50$ & 806,888 & 71,262 & 108,636 & 815 & 2.9 & 0.4 & 543 & 1039 \\
\hline C45/55 & 857,635 & 74,786 & 108,443 & 854 & 3.7 & 0.5 & 570 & 1093 \\
\hline $\mathrm{C} 50 / 60$ & 891,643 & 77,367 & 107,667 & 881 & 4.5 & 0.6 & 588 & 1129 \\
\hline C60/75 & 942,894 & 83,031 & 108,196 & 931 & 6.7 & 1.0 & 616 & 1188 \\
\hline $\mathrm{C} 70 / 85$ & 998,739 & 89,677 & 107,045 & 985 & 9.8 & 1.5 & 647 & 1254 \\
\hline C80/95 & $1,089,239$ & 100,170 & 113,761 & 1080 & 13.2 & 2.0 & 700 & 1367 \\
\hline Concrete Class & $\begin{array}{c}\text { GWP } \\
{\left[\mathrm{kg} \mathrm{CO}_{2} \text { eq.] }\right.}\end{array}$ & $\begin{array}{c}\text { FDP } \\
\text { [kg oil eq. }]\end{array}$ & $\begin{array}{c}\text { MDP } \\
\text { [kg Fe eq.] }\end{array}$ & $\begin{array}{c}\text { TAP } \\
{\left[\mathrm{kg} \mathrm{SO}_{2} \text { eq.] }\right.}\end{array}$ & $\begin{array}{c}\text { FEP } \\
{[\mathrm{kg} P \text { eq. }]}\end{array}$ & $\begin{array}{c}\text { ODP } \\
\text { [g CFC-11 eq.] }\end{array}$ & $\begin{array}{c}\text { PMFP } \\
{\left[\mathrm{kg} \mathrm{PM}_{10} \text { eq. }\right]}\end{array}$ & $\begin{array}{c}\text { POFP } \\
{[\mathrm{kg} \text { NMVOC eq. }]}\end{array}$ \\
\hline C30/37 & $1,285,161$ & 114,709 & 166,493 & 1309 & 2.6 & 0.3 & 958 & 1699 \\
\hline C $35 / 45$ & $1,395,450$ & 116,494 & 161,975 & 1363 & 3.9 & 0.5 & 949 & 1774 \\
\hline $\mathrm{C} 40 / 50$ & $1,394,545$ & 117,660 & 164,428 & 1364 & 5.1 & 0.6 & 936 & 1768 \\
\hline $\mathrm{C} 45 / 55$ & $1,360,061$ & 115,458 & 160,339 & 1330 & 5.9 & 0.8 & 902 & 1718 \\
\hline $\mathrm{C} 50 / 60$ & $1,314,075$ & 113,137 & 158,543 & 1292 & 6.6 & 0.9 & 866 & 1661 \\
\hline C60/75 & $1,360,180$ & 119,744 & 160,279 & 1342 & 9.7 & 1.4 & 889 & 1717 \\
\hline C70/85 & $1,405,043$ & 127,603 & 162,891 & 1398 & 14 & 2.0 & 912 & 1775 \\
\hline C80/95 & $1,485,146$ & 137,448 & 163,804 & 1480 & 18.0 & 2.7 & 955 & 1872 \\
\hline
\end{tabular}


Table A5. Variant with 12 stories and a column spacing of $4 \mathrm{~m}$.

\begin{tabular}{|c|c|c|c|c|c|c|c|c|}
\hline Strength Class & $\begin{array}{c}\text { GWP } \\
{\left[\mathrm{kg} \mathrm{CO} \mathrm{CO}_{2} \text { eq. }\right]}\end{array}$ & $\begin{array}{c}\text { FDP } \\
\text { [kg oil eq.] }\end{array}$ & $\begin{array}{c}\text { MDP } \\
\text { [kg Fe eq. }]\end{array}$ & $\begin{array}{c}\text { TAP } \\
{\left[\mathrm{kg} \mathrm{SO_{2 }} \text { eq.] }\right.}\end{array}$ & $\begin{array}{c}\text { FEP } \\
{[\text { kg P eq. }]}\end{array}$ & $\begin{array}{c}\text { ODP } \\
\text { [g CFC-11 eq.] }\end{array}$ & $\begin{array}{c}\text { PMFP } \\
\text { [kg } \text { PM }_{10} \text { eq.] }\end{array}$ & $\begin{array}{c}\text { POFP } \\
{[\mathrm{kg} \text { NMVOC eq. }]}\end{array}$ \\
\hline C20/25 & 935,008 & 88,019 & 138,010 & 998 & 0.8 & 0.0 & 727 & 1279 \\
\hline $\mathrm{C} 25 / 30$ & 955,372 & 88,991 & 140,593 & 1010 & 0.8 & 0.0 & 729 & 1294 \\
\hline C30/37 & $1,009,107$ & 93,168 & 140,835 & 1052 & 2.0 & 0.2 & 753 & 1347 \\
\hline C $35 / 45$ & $1,138,101$ & 98,499 & 144,303 & 1139 & 3.2 & 0.4 & 775 & 1463 \\
\hline C40/50 & $1,154,759$ & 100,915 & 148,685 & 1157 & 4.2 & 0.5 & 776 & 1481 \\
\hline C45/55 & $1,228,305$ & 106,145 & 149,116 & 1216 & 5.3 & 0.7 & 815 & 1559 \\
\hline C50/60 & $1,277,013$ & 109,804 & 147,773 & 1254 & 6.4 & 0.9 & 841 & 1610 \\
\hline C60/75 & $1,342,429$ & 117,632 & 149,918 & 1320 & 9.6 & 1.4 & 876 & 1688 \\
\hline C70/85 & $1,421,369$ & 126,906 & 147,382 & 1397 & 14.0 & 2.1 & 920 & 1780 \\
\hline C80/95 & $1,502,717$ & 136,860 & 147,974 & 1479 & 18.3 & 2.8 & 964 & 1877 \\
\hline Strength Class & $\begin{array}{c}\text { GWP } \\
{\left[\mathrm{kg} \mathrm{CO}_{2} \text { eq. }\right]}\end{array}$ & $\begin{array}{c}\text { FDP } \\
\text { [kg oil eq.] }\end{array}$ & $\begin{array}{c}\text { MDP } \\
\text { [kg Fe eq.] }\end{array}$ & $\begin{array}{c}\text { TAP } \\
{\left[\mathrm{kg} \mathrm{SO} \mathrm{O}_{2} \text { eq.] }\right.}\end{array}$ & $\begin{array}{c}\text { FEP } \\
\text { [kg P eq.] }\end{array}$ & $\begin{array}{c}\text { ODP } \\
\text { [g CFC-11 eq.] }\end{array}$ & $\begin{array}{c}\text { PMFP } \\
{\left[\mathrm{kg} \text { PM }_{10} \text { eq.] }\right.}\end{array}$ & $\begin{array}{c}\text { POFP } \\
{[\mathrm{kg} \text { NMVOC eq.] }}\end{array}$ \\
\hline C30/37 & $1,844,126$ & 161,609 & 221,337 & 1855 & 3.7 & 0.4 & 1374 & 2420 \\
\hline C $35 / 45$ & $1,962,892$ & 162,060 & 217,024 & 1903 & 5.6 & 0.7 & 1333 & 2485 \\
\hline $\mathrm{C} 40 / 50$ & $1,926,652$ & 160,575 & 215,148 & 1869 & 7.0 & 0.9 & 1291 & 2430 \\
\hline C45/55 & $1,868,862$ & 157,990 & 215,596 & 1822 & 8.1 & 1.1 & 1239 & 2356 \\
\hline $\mathrm{C} 50 / 60$ & $1,816,574$ & 155,413 & 212,601 & 1778 & 9.1 & 1.3 & 1197 & 2290 \\
\hline C60/75 & $1,876,500$ & 164,336 & 215,157 & 1845 & 13.4 & 1.9 & 1226 & 2363 \\
\hline C70/85 & $1,902,965$ & 171,789 & 213,381 & 1885 & 18.6 & 2.8 & 1234 & 2397 \\
\hline C80/95 & $2,011,700$ & 185,145 & 214,561 & 1996 & 24.4 & 3.7 & 1293 & 2528 \\
\hline
\end{tabular}




\section{References}

1. OSN, Agenda 21, New York: United Nations, Rio de Janerio. 1992, pp. 1-351. Available online: https: //sustainabledevelopment.un.org/content/documents/Agenda21.pdf (accessed on 10 August 2020).

2. International Council for Research and Innovation in Building and Construction. Agenda 21 on Sustainable Construction; CIB: Rotterdam, The Netherlands, 1999.

3. Cembureau, Built in Concrete Made with Cement. 2020. Available online: Cembureau.eu (accessed on 10 August 2020).

4. Van Ruijven, B.J.; van Vuuren, D.P.; Boskaljon, W.; Neelis, M.L.; Saygin, D.; Patel, M.K. Long-term model-based projections of energy use and $\mathrm{CO}_{2}$ emissions from the global steel and cement industries. Resour. Conserv. Recycl. 2016, 112, 15-36. [CrossRef]

5. Sakai, K.; Shibata, T.; Kasuga, A.; Nakamura, H. Sustainability design of concrete structures. Struct. Concr. 2016, 17, 1114-1124. [CrossRef]

6. Hájek, P.; Fiala, C.; Kynčlová, M. Life cycle assessments of concrete structures-A step towards environmental savings. Struct. Concr. 2011, 12, 13-22. [CrossRef]

7. International Federation for Structural Concrete (Ed.) Environmental Design: State-of-Art Report; International Federation for Structural Concrete: Lausanne, Switzerland, 2004.

8. Sakai, K.; International Federation for Structural Concrete (Eds.) Environmental Design of Concrete Structures-General Principles: Technical Report; International Federation for Structural Concrete: Lausanne, Switzerland, 2008.

9. Hájek, P.; International Federation for Structural Concrete (Eds.) Integrated Life Cycle Assessment of Concrete Structures: State-of-the Art Report; International Federation for Structural Concrete: Lausanne, Switzerland, 2013.

10. Gartner, E.; Hirao, H. A review of alternative approaches to the reduction of $\mathrm{CO}_{2}$ emissions associated with the manufacture of the binder phase in concrete. Cem. Concr. Res. 2015, 78, 126-142. [CrossRef]

11. Qomi, M.J.A.; Krakowiak, K.J.; Bauchy, M.; Stewart, K.L.; Shahsavari, R.; Jagannathan, D.; Brommer, D.B.; Baronnet, A.; Buehler, M.J.; Yip, S.; et al. Combinatorial molecular optimization of cement hydrates. Nat. Commun. 2014, 5, 4960. [CrossRef] [PubMed]

12. Solidia®-Making Sustainability Business As UsualSM, (n.d.). Available online: https://www.solidiatech. $\mathrm{com} /$ (accessed on 27 July 2020).

13. Tam, V.W.Y.; Soomro, M.; Evangelista, A.C.J. A review of recycled aggregate in concrete applications (2000-2017). Constr. Build. Mater. 2018, 172, 272-292. [CrossRef]

14. Evins, R. A review of computational optimisation methods applied to sustainable building design. Renew. Sustain. Energy Rev. 2013, 22, 230-245. [CrossRef]

15. Shi, X.; Tian, Z.; Chen, W.; Si, B.; Jin, X. A review on building energy efficient design optimization rom the perspective of architects. Renew. Sustain. Energy Rev. 2016, 65, 872-884. [CrossRef]

16. Pal, S.K.; Takano, A.; Alanne, K.; Palonen, M.; Siren, K. A multi-objective life cycle approach for optimal building design: A case study in Finnish context. J. Clean. Prod. 2017, 143, 1021-1035. [CrossRef]

17. Roy, R.; Hinduja, S.; Teti, R. Recent advances in engineering design optimisation: Challenges and future trends. CIRP Ann. 2008, 57, 697-715. [CrossRef]

18. Machairas, V.; Tsangrassoulis, A.; Axarli, K. Algorithms for optimization of building design: A review. Renew. Sustain. Energy Rev. 2014, 31, 101-112. [CrossRef]

19. Mergos, P.E. Contribution to sustainable seismic design of reinforced concrete members through embodied $\mathrm{CO}_{2}$ emissions optimization: Sustainable seismic design of concrete members. Struct. Concr. 2018, 19, 454-462. [CrossRef]

20. Sahab, M.G.; Ashour, A.F.; Toropov, V.V. Cost optimisation of reinforced concrete flat slab buildings. Eng. Struct. 2005, 27, 313-322. [CrossRef]

21. Cenová soustava ÚRS (CS ÚRS), (n.d.). Available online: https://www.pro-rozpocty.cz/software-a-data/ cenova-soustava-urs-cs-urs-/ (accessed on 23 July 2020).

22. ISO 14040:2006 Environmental Management-Life Cycle Assessment-Principles and Framework. 2006. Available online: https://www.iso.org/standard/37456.html (accessed on 10 August 2020).

23. ISO 14044:2006 Environmental Management—Life Cycle Assessment—Requirements and Guidelines. 2006. Available online: https://www.iso.org/standard/38498.html (accessed on 10 August 2020). 
24. Guinee, J. Handbook on life cycle assessment-Operational guide to the ISO standards. Int. J. Life Cycle Assess. 2001, 6, 255. [CrossRef]

25. EN 15804:2012+A1:2013 Sustainability of Construction Works-Environmental Product Declarations-Core Rules for the Product Category of Construction Products. 2013. Available online: https://standards.cen.eu/dyn/www/f?p=204:110:0::::FSP_PROJECT,FSP_ORG_ID:40703,481830\& Cs=1B0F862919A7304F13AE6688330BBA2FF (accessed on 10 August 2020).

26. GaBi Professional, n.d. Available online: http://www.gabi-software.com/databases/professional/ (accessed on 27 November 2019).

27. Goedkoop, M.J.; Huijbregts, R.; De Schryver, A.; Struijs, J.; van Zelm, R. ReCiPe 2008: A Life Cycle Impact Assessment Method Which Comprises Harmonised Category Indicators at the Midpoint and the Endpoint Level, The Netherlands. 2013. Available online: https://www.researchgate.net/publication/302559709_ReCiPE_2008_A_life_cycle_impact_assessment_ method_which_comprises_harmonised_category_indicators_at_the_midpoint_and_the_endpoint_level (accessed on 16 January 2020).

28. Sleeswijk, A.W.; van Oers, L.F.C.M.; Guinee, J.B.; Struijs, J.; Huijbregts, M.A.J. Normalisation in product life cycle assessment: An LCA of the global and European economic systems in the year 2000. Sci. Total Environ. 2008, 390, 227-240. [CrossRef] [PubMed]

29. Hajek, P. Integrated environmental design and optimization of concrete floor structures for buildings. In Proceedings of the 2005 World Sustainable Building Conference, Tokyo, Japan, 27-29 September 2005; pp. 2-29.

Publisher's Note: MDPI stays neutral with regard to jurisdictional claims in published maps and institutional affiliations. 